\title{
'Examining the adoption and use of graphic novels as a learning resource in Hamilton schools'
}

by

\section{Bryony Anne Walker}

\footnotetext{
Submitted to the School of Information Management,

Victoria University of Wellington

in partial fulfilment of the requirements for the degree of Master of Library and Information Studies
} 


\section{Acknowledgements}

I wish to thank my supervisor Prof Gary Gorman for his advice and guidance, as well as LIM Programmes Director Brenda Chawner and senior tutor Lynley Stone for their assistance and support. I would also like to acknowledge my colleagues at the Hamilton Central Library, and in particular those in the Community Programmes Team, for being a sounding board when I needed one. But most of all, I wish to thank my fiancé Aaron, who kept me focused in times of distraction, and whose love and support kept me moving forwards. 
VICTORIA UNIVERSITY OF WELLINGTON

School of Information Management

Master of Library \& Information Studies

IMPORTANT DISCLAIMER

with respect to a MLIS Research Project (INFO 580)

\title{
'Examining the adoption and use of graphic novels as a learning resource in Hamilton schools'
}

\section{(hereafter referred to as 'The MLIS Research Project')}

\author{
being undertaken by
}

\section{Bryony Anne Walker}

in partial fulfilment of the requirements of the degree of Master of Library and Information Studies,

School of and Information Management, Victoria University of Wellington.

\section{Topic Commencement: November 2008}

1. Victoria University of Wellington and its Council, its members, staff, employees, students and agents undertake no duty of care in contract, tort, or otherwise, to users (whether direct or indirect) of the MLIS Research Project and make no warranties or representations of any kind whatsoever in relation to any of its contents.

2. The MLIS Research Project is only made available on the basis that all users of it, whether direct or indirect, must take appropriate legal or other expert advice in relation to their own circumstances and must rely solely on their own judgement and such legal or other expert advice.

3. Under no circumstances will Victoria University of Wellington and its Council, its members, staff, employees, students or agents be liable in any way whatsoever, whether in contract, tort (including negligence), for breach of any statutory or regulatory duty (to the fullest extent permissible by law), or otherwise, to any user (whether direct or indirect) of the MLIS Research Project for any loss or damage whatsoever arising directly or indirectly as a result of the use in any way of the MLIS Research Project.

4. Each exclusion in the clauses of this disclaimer and each protection given by it is to be construed as a separate exclusion applying and surviving even if for any reason any of the exclusions or protections are held inapplicable in any circumstance. 


\section{Contents}

\section{Abstract}

Keywords

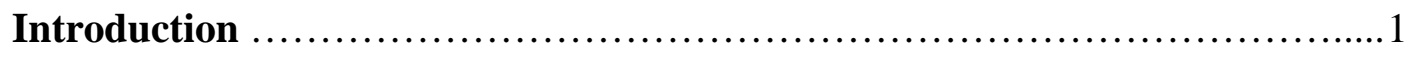

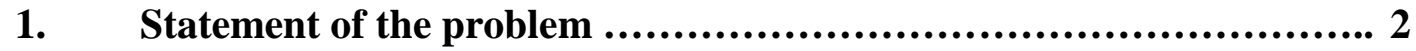

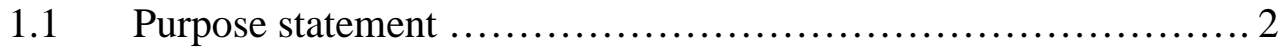

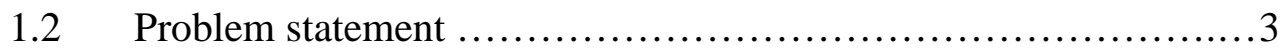

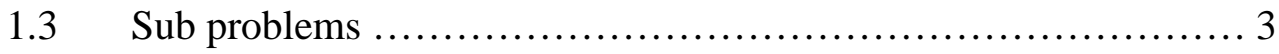

$1.4 \quad$ Research questions ........................................ 3

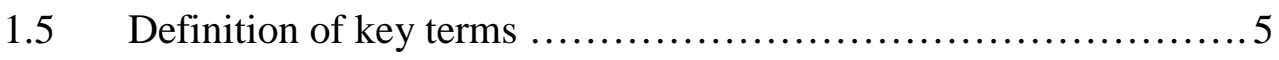

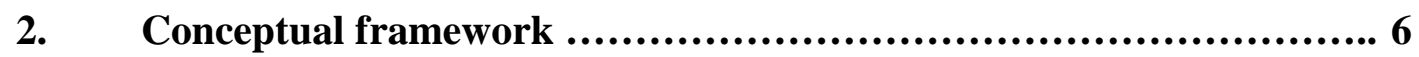

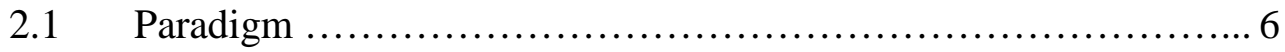

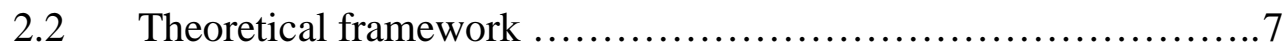

3. Literature review .................................................. 9

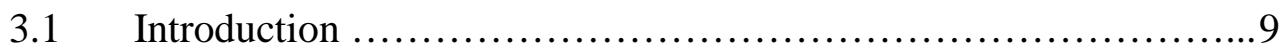

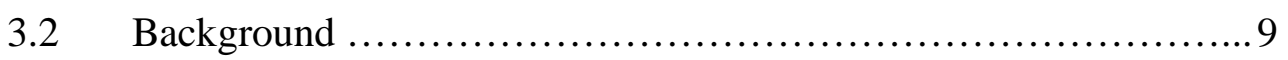

3.3 Visual literacy and multiple literacies ....................... 10

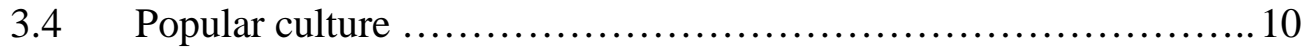

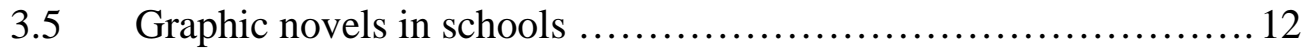

3.6 Reluctant readers, foreign language students, and boys ............ 13

3.7 Graphic novels in New Zealand ............................... 15

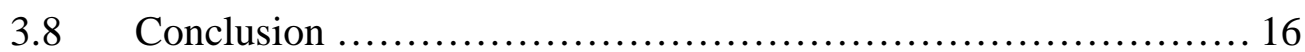

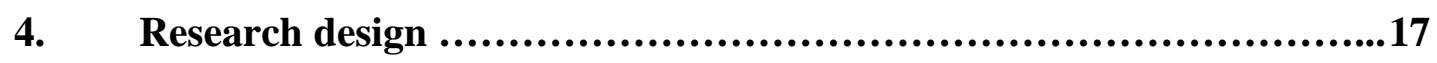

4.1 Methodology ............................................ 17

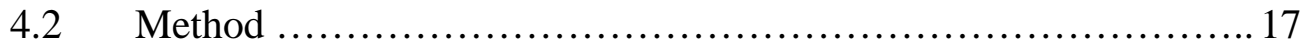

4.2.1 Chosen methods ...................................... 17

4.2.2 Research sample .....................................18

4.2 .3 Pilot study ......................................... 19

4.2.4 Limitations and delimitations ............................. 20

4.2.5 Ethics ................................................ 21

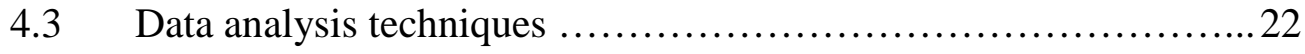

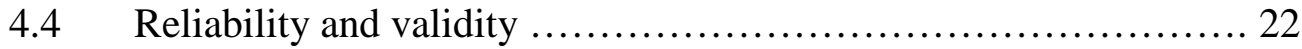




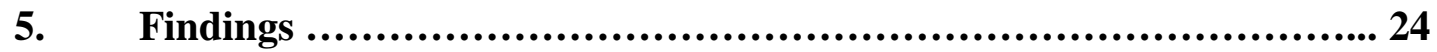

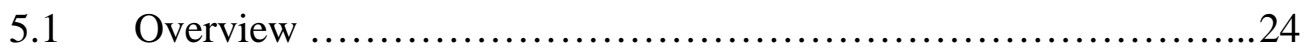

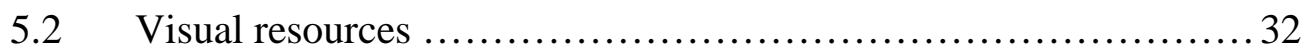

5.3 School programmes and activities involving graphic novels ......... 35

5.4 Types of graphic novels selected for use ….................... 37

5.5 Benefits of using graphic novels in schools ........................ 39

5.6 Changes to students' skills and attitudes .......................... 43

5.7 Student responses to graphic novels in schools ..................... 45

6. Discussion and analysis ....................................................47

6.1 Role of libraries in advocating for graphic novels ...............47

6.2 Acceptance as an educational tool $\ldots \ldots \ldots \ldots \ldots \ldots \ldots \ldots \ldots \ldots \ldots . \ldots . \ldots \ldots$

6.3 Need for balanced collection of resources ..................... 50

$6.4 \quad$ Impact on students ....................................... 51

6.5 Tension between access and content ......................... 54

6.6 Limitations as a resource .................................... 55

6.6.1 Age ................................................. 55

6.6.2 Socio-economic status ................................. 56

7. Conclusions and recommendations .................................58

7.1 Implications for future research ........................... 59

\section{Appendices}

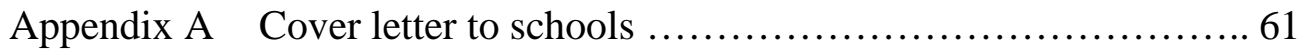

Appendix B Participation information sheet ............................63

Appendix C Research participation consent form .......................65

Appendix D Guideline interview questions .............................66

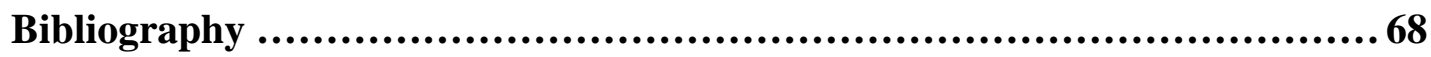

\section{Figures}

Figure 1 


\begin{abstract}
Graphic novels have grown in popularity during last 20 years. A growing band of supporters are advocating for graphic novels to be used in both public libraries and schools. However, research into this area in New Zealand is limited. This study investigated the current situation by exploring how Hamilton teachers and school librarians were utilising graphic novels and their experiences during these activities. A qualitative approach of semi-structured interviews with volunteer participants was chosen in order to solicit rich information on the phenomenon. The study found the use of graphic novels in schools was an emerging phenomenon and the format was being used to a limited extent. However, both teachers and librarians felt they were a successful learning tool with many benefits for students. These included increased enthusiasm and engagement from students, in particular boys and reluctant readers, a focus on visual literacy skills, and connections with popular culture. All participants recommended graphic novels have a place in schools in the future, highlighting the potential they have as a legitimate learning resource. This study recommends graphic novels continue to be used in schools or be adopted by those schools without them. It also recommends schools select a wide range of graphic novel genres in order to cater to the needs of the variety of students identified as responding positively to the format.
\end{abstract}

\title{
Keywords
}

- Graphic novels

- Learning resources

- Multimodal meaning

- Popular culture

- Visual literacy 


\section{Introduction}

In 2008 graphic novel sales in the United States and Canada alone hit \$395 million (Reid, 2009). Of this, libraries represented around \$25 million in sales. In public and school libraries around the world, graphic novels are constantly on loan and heavily reserved by patrons, especially teens (Andera, 2007; Gorman, 2003; Lyga \& Lyga, 2004; McPherson, 2006; Serchay, 2004; Weiner, 2001; Young, 2007). Recent literature on graphic novels indicates the growth in graphic novels is a worldwide phenomenon, with many librarians advocating graphic novels as a tool to encourage reluctant readers, and in particular boys, to read voluntarily (Crawford, 2004; Foster, 2004; Frey \& Fisher, 2004; Gorman, 2003; Lyga \& Lyga, 2004; Weiner, 2001). Others have seen the benefits of graphic novels as educational tools and are encouraging their use in schools to foster literacy and cater to the visual learning needs of students (Albright \& Walsh, 2003; Carlson, 2008; Laycock, 2007; McElmeel, 2008; Teale, Kim \& Boerman-Cornell, 2008). However, there are also opponents of graphic novels who feel strongly that the content is too graphic and the themes inappropriate for young readers (Albright \& Walsh, 2003; Brenner, 2006; Censorship Dateline, 2007; Eisner, 2003; Fitzsimmons, 2007; Mori, 2007; Watts, 2003). They also feel the novels do not foster literacy skills because they are too visual, thus failing to encourage students to use their own imagination (Jacobs, 2007; British Schools, 1998). However, in New Zealand there has been little research into graphic novels and in particular their use in schools. This study aimed to examine to what extent Hamilton schools had adopted graphic novels as a learning resource, how they were introducing them to students, and the students' responses to their use. This was done by exploring teachers' and school librarians' experiences using graphic novels as learning tools. 


\section{Statement of the problem}

\subsection{Purpose statement}

The purpose of the study was to investigate the use of graphic novels in Hamilton schools by recording the experiences of teachers and school librarians who were encouraging the use of graphic novels as a learning tool in order to better understand the current situation. This allowed the identification of what phase Hamilton was in when examining the adoption of the graphic novels in schools. This study also aimed to provide a formal base of research which could be used to assist other New Zealand teachers who might be considering implementing visual learning programmes involving graphic novels, but who were struggling to find local data on the phenomenon to influence their decision. It might also provide school librarians with a formal platform from which they could argue for the inclusion of graphic novels in New Zealand school libraries.

This exploration was done through a qualitative study involving interviews with teachers, teacher-librarians or school librarians who used graphic novels in school programmes and activities. This approach allowed the researcher to gather rich indepth information (Creswell, 2009), which built on previous studies done on graphic novels in public libraries (Boyd, 2000) and the use of visual resources in the classroom (McDowall, 2004) to help build a picture of the success or otherwise of graphic novels as a visual learning resource. Knowing how successful graphic novels were as a visual resource in New Zealand schools could help determine future approaches to school curricula and influence school library collection development policies. More research is needed to cement beyond doubt the place of graphic novels in schools. The more official research is published, the more the practice of including graphic novels will be accepted. 


\subsection{Problem statement}

There is little information on the extent to which graphic novels are used as a learning resource in New Zealand schools. This lack of formal research may be hindering the uptake of graphical novels as a visual learning resource, as teachers and librarians may be hesitant to introduce a learning tool without some empirical data confirming its value in the school environment, or without any guidance on suitable programmes or activities in which they can be included. While this is available at an international level, it is not at a national level. Every country has a different educational curriculum, and knowing how successfully a resource fits into your own curriculum is a far more valuable measure of its potential than relying purely on overseas data.

\subsection{Sub problems}

- We do not know how New Zealand teachers and librarians are using graphic novels as a learning resource in schools.

- We do not know how successful graphic novels are as a learning resource in New Zealand.

- We do not know how students are responding to the use of graphic novels in education in New Zealand.

- We do not know which students respond best to the use of graphic novels in school activities in New Zealand.

\subsection{Research questions}

\section{Overall research question:}

To what extent have Hamilton schools adopted graphic novels as a learning resource and how successful have they been as a visual learning tool? 


\section{Sub questions:}

- What value do teachers place on visual resources in the classroom? This will indicate whether there is a greater emphasis on visual resources then there has been in the past. This knowledge could help school librarians in their acquisition of new resources and collection development policies.

- How are teachers and school librarians introducing graphic novels into school programmes and activities? This will examine the types of activities teachers and librarians use graphic novels in. It will indicate if graphic novels are the main focus of activities or if they only play a minor role in school resources. It will also show what subjects and parts of the curriculum are best supported by the use of graphic novels. This knowledge will help school librarians provide the right balance in resources between graphic novels and traditional print novels.

- What types of graphic novels are teachers and school librarians using? This will show whether schools are using more recreational-focused graphic novels, such as superhero graphic novels, or more educational ones, such as Shakespeare in graphic novel format. This may indicate to school librarians the type of graphic novels to provide in their libraries.

- What benefits do teachers and librarians feel graphic novels bring to schools? This will show how graphic novels are helping improve learning in schools, both in classrooms and libraries.

- What changes in students' skills and attitudes have teachers and librarians observed when using graphic novels? This will show if graphic novels are having a positive impact on students and in what ways students' learning and attitudes to learning have changed through their use.

- Do particular groups of students respond better to graphic novels than others? This will gauge how students themselves are responding to graphic novels and highlight if there are certain groups of students who respond better to the use of 
graphic novels as a learning resource and therefore could be targeted in future educational and library programmes involving the resource.

\subsection{Definition of key terms}

\section{Graphic novels}

Graphic novels and comic books are visual texts, which combine words and images to create what is termed sequential art (Eisner, 2003). However, graphic novels are considered to be longer and involve a complete story (Lyga \& Lyga, 2004).

\section{Learning resources}

Learning resources are materials used for learning which are made accessible in a library or school (Oxford English Dictionary, 1989). Graphic novels are an example of one type of learning resource.

\section{Multimodal meaning}

Multimodal meaning is a form of meaning making where more than one mode of meaning or literacy is required to build understanding (Cazden et al, 1996). Therefore, it draws on multiple forms of literacy to create meaning (Jacobs, 2007).

\section{Popular culture}

Popular culture is the cultural traditions of ordinary people (Oxford English Dictionary, 1989). Popular culture includes a variety of media, including books, movies, television, advertising, fashion and music (Brooks, 2008).

\section{Visual literacy}

Visual literacy encompasses a group of skills which focus on the vision-competencies of a person and allow that person to create understanding and meaning by interpreting images and communicating using those images (Avgerinou \& Ericson, 1997). 


\section{Conceptual framework}

\subsection{Paradigm}

This project used an interpretivist paradigm (Pickard, 2007) due to the social nature of the study, as it examined the current situation within a natural setting, that of schools, and sought understanding of that situation (Creswell, 2009). This research aimed to investigate a knowledge void by examining teachers' and librarians' use of graphic novels in Hamilton schools. It was hoped this would expose, through exploring their personal experiences, the current thinking by teachers and school librarians towards graphic novels as a learning resource. This insight may then be used by other teachers to assess the viability of using graphic novels as a legitimate learning tool.

Within the interpretivist paradigm, the researcher used a qualitative approach of semistructured interviews with teachers (Creswell, 2009). The type of research conducted fell into the phenomenological strategy of qualitative research, which aimed to examine study participants' experiences concerning a phenomenon (Creswell, 2009; Fraenkel \& Wallen, 2006; Grbich, 2007). By examining first-hand experiences, it was hoped the essence of the phenomenon would be revealed, thus adding to the conscious knowledge of the phenomenon (Grbich, 2007). This strategy was chosen because the open-ended questions associated with first-person qualitative interviews could provide a rich source of data from which to develop themes and build knowledge (Creswell, 2009; Grbich, 2007). Teachers and school librarians are in the best position for observing trends in education, as they are at the forefront of educational initiatives, both having to implement programmes and observe the results of them. Data collection was also interactive, meaning the researcher had the ability to explore issues raised in interviews and develop a level of detail not available in quantitative methods (Creswell, 2009). 


\subsection{Theoretical framework}

This research project was framed in the light of the New London Group's Multiliteracies Theory. This theory asserts that there are numerous ways in which humans build cognitive understanding and each of these ways of learning must be given the same emphasis in educational practices. In particular, this research is drawing on the visual literacy aspect of the Multiliteracies Theory, as graphic novels are often considered a visual learning tool.

The Multiliteracies Theory was first put forward in 1996 by a group of educators calling itself the New London Group. It advocates for a broader approach to literacy than traditional language-based approaches in order to meet the needs of modern societies dominated by technology and where cultural and linguistic diversity is becoming the norm (Cazden et al, 1996). The authors assert that working, public and private lives are changing and therefore schools must change to meet the needs of a new generation. Schools need to be aware of the different methods of identifying meaning, in particular where textual meaning is related to visual, audio, spatial and behavioural meaning. The New London Group includes six designs of meaningmaking, or multiliteracies: linguistic, visual, audio, gestural, spatial and multimodal. This research aimed to examine how one of these designs, visual meaning-making, was being addressed in classrooms through the use of graphic novels and how this emphasis on visual meaning-making may be helping students improve their learning.

Traditionally schools have concentrated on linguistic and logical-mathematical skills, but unfortunately not all students have been successful under this approach (Gardner, 1999). There is now recognition in many schools of a need to broaden literacy education to include forms of literacy which have become prominent due to changing technology (Albright \& Walsh, 2003; Brooks, 2008; Frey \& Fisher, 2004; Gorman, 2003; Lyga \& Lyga, 2004; McDowall, 2004). In particular there is a push to recognise the importance of visual literacy. The Multiliteracies Theory stresses that students are growing up in a visually intense world where they must interpret images on a daily basis from television, movies, and magazines, to billboard advertising, web pages, and computer games (Cazden et al, 1996). To cope with this, students and teachers need to be flexible and have a variety of tools at their disposal (Cazden et al, 1996). Graphic 
novels fit well into this pedagogy as they are now recognised as a multimodal medium by many in the library and education sectors (Jacobs, 2007; McPherson, 2006;

Schwarz, 2002; Williams, 2008). Many also believe they stimulate critical thinking by encouraging readers to examine the relationship between the images, text and layout of the pages (Carlson, 2008; McPherson, 2006). In particular, graphic novels may be able to assist with visual literacy, and this research examined how they were used in schools to achieve this. 


\section{Literature review}

\subsection{Introduction}

This literature review examines the current attitudes towards graphic novels and their potential value as a learning resource in Hamilton schools. While literature specifically relating to graphic novels in New Zealand is limited, there is much overseas literature dealing with the topic. The literature falls into two areas: education-focused and library-focused literature. The educational literature, using concepts gained from Multiliteracies Theory, addresses the importance of visual media in creating a holistic approach to education. It outlines the value of visual learning techniques for students, especially reluctant readers. The library literature focuses on the place of graphic novels in school and public libraries. All of this builds a picture of an emerging phenomenon that has the power to help young people engage more positively with reading.

\subsection{Background}

Graphic novels first appeared around the late 1970s, with many crediting Will Eisner with introducing the format (Frey \& Fisher, 2004; Heaney, 2007; Kan, 2003; Mori, 2007). Comics have been around for much longer (Weiner, 2003). But it is the emergence of graphic novels over last 20 years and their growing popularity that has caught the attention of many librarians and scholars alike and has raised the question of the role graphic novels can play in modern education practices.

It is important to clearly define each format. Eisner (2003) defines comic books as presenting a "montage of both word and image" (p. 8), to create what he terms as sequential art. Graphic novels, although based on the same sequential art as comics, are considered "more weighty and arty versions of the comic book" (Murray, 2007, p. 19). Lyga and Lyga (2004) offer a fuller definition. They describe graphic novels as more like traditional novels, as they are longer and have a complete story in each book, in contrast to many comics, which are serial in nature. They also make the distinction that all graphic novels are comic books, but not all comic books are 
graphic novels. It is important to stress that a graphic novel is a format and not a genre (Heaney, 2007; Kan, 2003). Included in this format is manga, a form of graphic novel originating in Japan which normally includes wide-eyed characters and is read back to front (Gorman, 2008).

\subsection{Visual literacy and multiple literacies}

Young people today are growing up in a world brimming with visual images, from advertising to television to computers and more. Because of this, visual literacy is gaining prominence as a genuine form of literacy within the education sector (Schwarz, 2002).

One theory that recognises this changing environment is the New London Group's Multiliteracies Theory (Cazden et al, 1996). This theory asserts that there are numerous ways in which humans build cognitive understanding, including literacies based on linguistic, visual, audio, gestural, spatial and multimodal skills. Therefore, a variety of resources are needed to cater to each individual's preferred method of learning and to address the range of literacies children now have to deal with. The New London Group argues that by taking a broader approach to literacy than traditional language-based approaches, educators are more likely to meet the needs of modern societies dominated by technology and where cultural and linguistic diversity has become the norm. Frey and Fisher (2004) believe in this pedagogy, and argue that many reading intervention programmes fail to recognise multiple literacies. They believe using popular culture, such as graphic novels, in the classroom builds on students' multiple literacies, thus catering to the needs of more children. As well as Frey and Fisher, others who have associated multiple literacies with graphic novels include Albright and Walsh (2003), Jacobs (2007), McPherson (2006), and Schwarz (2002).

\subsection{Popular culture}

Because of the visual world they live in, young people today are exposed to popular culture such as advertising, comics, movies, television, and computer games on an almost daily basis. They enjoy being immersed in popular culture and feel connected 
to it (Brooks, 2008). By bridging the gap between learning and popular culture, educators can tap into resources which appeal to students and will encourage them to learn (Albright \& Walsh, 2003; Brooks, 2008; Hughes-Hassell \& Rodge, 2007).

Many comics and graphic novels have now been turned into films, including Batman, Superman, and The Fantastic Four. The conversion industry is booming with more released in 2009, including The Spirit, Watchmen, X-Men Origins: Wolverine, and Dragonball Evolution, which is based on a manga series. In turn, after seeing their heroes on screen, many children are clambering for more, hitting book stores and libraries in search of comics and graphic novels. Weiner (2001), Foster (2004) and Gorman (2003) are among those advocating for these graphic novel titles to be kept in libraries because of their connection to popular culture.

Many teachers do not take graphic novels seriously because they are popular culture and therefore won't use them in classrooms (Albright \& Walsh, 2003; Mori, 2007; Fitzsimmons, 2007; Watts, 2003). A solid foundation of research is beginning to emerge which aims to contradict this perception. Albright and Walsh (2003) investigated what they termed culture jamming. This involves using visual culture, such as advertising and mass media, in classrooms as an alternative teaching method. They found this type of teaching catered to the multiple literacies of modern students and helped increase students' critical analysis skills.

Frey and Fisher (2004) also investigated the use of popular culture, in this case in an urban high school ninth-grade writing class designed for struggling students. Using action research, they introduced graphic novels to the students through shared reading followed by a discussion of meaning, vocabulary, tone and mood. The students then wrote their own story using the words and themes discussed. Frey and Fisher observed their responses, noting how confidence grew and that there was "more evidence of complex sentences and multiple ideas in students' work" (p.22). They concluded by stating that using popular culture in lessons not only improved students' writing, but students also become more knowledgeable consumers of information. The methodology proved a successful approach as it allowed the researchers to monitor the impact introducing graphic novels had and compare writing results before and after the intervention. This study involved a diverse range of struggling readers, 
including those who spoke English as a second language. However, the study involved only 32 students, which means the sample is too small to be able to successfully generalise to other situations (Kemper, Stringfield, \& Teddlie, 2003).

In some cases young people do not identify with traditional books because they are unable to relate to the stories told in them. Recent research into the use of the electronic resource The Game and other stories in New Zealand schools exemplifies this (McDowall \& Boyd, 2003; McDowall, 2004). The mixed method study followed 11 students, chosen from purposive sampling and classed as reluctant readers, as they worked through a four-week unit based around the interactive CD-ROM The Game and other stories. Interviews, logs, observation and reading tests were used to record data (McDowall \& Boyd, 2003). It was found that students in this study particularly enjoyed being able to identify with characters and storylines in the electronic books and found the themes relevant to their lives (McDowall, 2004). Although this research does not include graphic novels, the results could be mapped to other visual resources such as graphic novels. This study is particularly relevant to the current study as it is a New Zealand study which indicates there are initiatives being implemented which address multiple literacies, and in particular visual literacy. It also included interviews, which produced a rich set of data. However, the short length of the research meant student achievement was limited (McDowall \& Boyd, 2003) and the small sample meant results could not be generalised (Kemper, Stringfield, \& Teddlie, 2003).

\subsection{Graphic novels in schools}

There have been several other studies, as well as those listed above, conducted in schools looking at visual literacy and the place of graphic novels in classrooms and school libraries. Most are qualitative, either involving observational studies (Albright \& Walsh, 2003; Andera, 2007; Bergin, 2005; Cho, Choi \& Krashen, 2005;

Fitzsimmons, 2007; Frey \& Fisher, 2004; Schneider, 2007), or case studies, interviews and focus groups (Lamanno, 2007; Laycock, 2007; Norton, 2003; Ranker, 2007; Walton, 2007). However, because the observational studies are from personal experience, it is hard to map those results to other situations. Samples are generally small and each situation has its own variables, influencing factors, and bias on the part 
of the observer or researcher, making generalising difficult. Nevertheless, research findings were generally positive for the use of popular culture, including graphic novels, as a reading resource in the classroom. Many showed that graphic novels increase the engagement of students with the text, increased their critical understanding, and improved comprehension (Albright \& Walsh, 2003; Frey \& Fisher, 2004; Lancy \& Hayes, 1988; Laycock, 2007).

One study which exemplifies these findings is Laycock's (2007) research into reading Macbeth. Here the use of the mainstream text and the graphic novel version of the play were compared within two classes of Year 8 boys. There was evidence that the boys developed cognitive engagement with the graphic novel, often discussing the visual nature and artist's interpretation of the play. There were also positive signs of behavioural engagement, with boys staying interested in the work throughout the unit, which was not seen with the traditional text.

However, Laycock noted that not all the boys enjoyed reading the graphic novel version. The reasons for this were varied and did not point to one factor. Therefore, Laycock felt there was a place for graphic novels in the curriculum, but not as replacement for traditional resources. This reinforces the Multiliteracies Theory, which advocates for a variety of resources which can cater to the multiple literacies of modern society (Cazden et al, 1996), and implies the curriculum needs to be balanced to cater to all learning needs.

\subsection{Reluctant readers, foreign language students and boys}

A major theme identified in the literature is the connection between graphic novels and those classed as reluctant or struggling readers (Crawford, 2004; Lyga \& Lyga, 2004; Snowball, 2005), and in particular boys and students learning English as a second language. Reluctant readers can be described as unmotivated or lacking the skills required to construct meaning through reading (Lyga \& Lyga, 2004).

Literature advocating graphic novels as a successful learning tool for adolescent males is growing in prevalence (Andera, 2007; Gowing, 2006; Laycock, 2007; Walton, 2007; Welldon, 2005). Many authors feel that boys already have a connection with the 
format through associations with popular culture, and are therefore more likely to respond to programmes involving graphic novels. Two studies focused solely on boys' reactions to the introduction of graphic novels, with both studies showing positive increases in skills and motivation. Laycock (2007), as mentioned earlier, found cognitive and behavioural engagement increased during the study, while Walton (2007) identified six specific strategies boys utilised when reading graphic novels. Walton used an interpretivist paradigm to design the study and utilised both interviews and focus groups to attain the qualitative data. This proved successful, allowing the study to progress from the general to the specific and eventually identifying the six strategies from the data recorded.

Cho, Choi and Krashen (2005), Frey and Fisher (2004) and Ranker (2007) focused their studies on students who spoke English as a second language. All used qualitative approaches to attempt to build understanding with their students. Their methods included reading aloud, sustained silent reading and using graphic novels as writing prompts. All noticed students' engagement with the images helped them to increase their understanding of vocabulary, context, and tone. Cho, Choi and Krashen also found students' motivation to read increased.

However, one study has contradicted previous results. Lamanno (2007) used a reading intervention programme to investigate the use of graphic novels with students with severe reading difficulties and found no significant improvement in their skills. This may be due to the short length of the study (nine weeks) and the existing lack of skills of the participants. Lamanno concluded that for this level of learning disability, an intensive programme of substantial length would be required before any improvements were witnessed. However, because the study used mixed methods and concluded with an open-ended questionnaire designed to solicit qualitative data from students, Lamanno was able to assess students' responses to the programme. Many said they enjoyed working with graphic novels and they felt the programme had helped improve their skills. This perception may be more from the students feeling comfortable using the books, as opposed to any real improvement in skills. 


\subsection{Graphic novels in New Zealand}

There has been limited research published in New Zealand on graphic novels in general and even less on graphic novels as a learning resource in schools. What has been published shows the steady progression visual mediums have made, but the lack of published material indicates a need for further investigation.

In 1994, Lee-Smith found there were only two public library comic collections in New Zealand. However, circulation statistics at one of those libraries were extremely high. While insightful, Lee-Smith's article is anecdotal and does not involve any indepth research.

In 2000, when Boyd conducted research using mixed methodology to investigate graphic novels in New Zealand public libraries, the research was still absent. Boyd's survey of district libraries found of the 44 respondents, 25 now had graphic novel collections. The case study found 56 percent of readers using the graphic novel collection currently attended primary or secondary school, while 66 percent were aged 13-17 years old. This shows there is much interest in the format from young people. Boyd's research mainly produced statistical data. While good for providing a general overall picture, the scope still remains for more qualitative research which investigates the reasons behind the phenomenon.

In 2002, Crawford conducted a basic quantitative study into graphic novels in New Zealand by asking 30 students in Year 8 to read a selection of comic books and graphic novels and answer a questionnaire. Although Crawford admits the results are brief and inconclusive, he did note the books had a positive reception from both girls and boys and that majority of students wanted the material used in classroom work. While this study lacks depth, it does indicate there is scope for more research, especially within the classroom setting.

This timeline shows the growing popularity of graphic novels in both schools and libraries in New Zealand. However, the studies are only a beginning and more indepth research is required to effectively define the role of graphic novels in schools as a learning resource. 


\subsection{Conclusion}

Graphic novels have been a growing phenomenon over the last 20 years. Their visual nature has appealed to those pushing the Multilitercies Theory. Also the fact that young people today view graphic novels as popular culture, and thus identify with the material, means graphic novels are in a perfect position to be used in the classroom. There is a solid base of qualitative research, including observations, interviews, focus groups and action research, being done overseas into graphic novels, which shows very positive signs for the classroom use of visual mediums. However, a search of the literature shows very little research has been done in New Zealand into the subject. So how are educators introducing visual mediums such as graphic novels into the classroom? Are they successful as a learning resource? And who is benefiting the most from their use in classrooms? Research in this area is undeveloped and there is certainly scope for more in-depth investigations. 


\section{Research design}

\subsection{Methodology}

This project involved a qualitative research approach (Pickard, 2007) involving semistructured interviews with selected teachers, teacher-librarians or school librarians from Hamilton city schools. A qualitative approach was chosen because it offered the opportunity to explore the reasons behind the phenomenon of graphic novels and it provided a deeper understanding of the situation than possible with quantitative research (Gorman \& Clayton, 1997). This would help build a platform to launch further research.

There have been many qualitative studies conducted overseas into graphic novels and their use in schools (Albright \& Walsh, 2003; Andera, 2007; Bergin, 2005; Fitzsimmons, 2007; Frey \& Fisher, 2004; Lancy \& Hayes, 1988; Laycock, 2007; Norton, 2003; Schneider, 2007; Snowball, 2007; Walton, 2007). These studies provide evidence that a qualitative approach can provide a rich source of information. Many of the studies were observational, often completed by educators or teachers working in the field and investigating their students' responses to graphic novels (Albright \& Walsh, 2003; Fitzsimmons, 2007; Frey \& Fisher, 2004; Lancy \& Hayes, 1988; Laycock, 2007; Schneider, 2007; Walton, 2007). This led to the present project as it was seen how much insight personal experiences of those in the field could yield on the phenomenon.

\subsection{Method}

\subsubsection{Chosen methods}

The method selected for this project was semi-structured face-to-face interviews with selected teachers, teacher-librarians and school librarians, as this was a well-tested means of gathering rich data on the subject (Pickard, 2007). An open-ended interview technique directed by an interview guide (see Appendix D) was used with the aim of soliciting richer data than would be 
possible with a closed, fixed response interview (Gorman \& Clayton, 1997; Pickard, 2007). Because of the inexperience of the researcher, an informal conversational interview technique was ruled out. Questions were designed to reflect the major issues identified in the literature review and the research questions posed at the beginning of the project. The interview questions were not used to restrict responses, but rather to provide a framework for discussion.

Two studies in particular which used qualitative interviews guided this research project. Norton (2003) showed the power of interviews to solicit rich data when interviewing child readers of Archie comics. Norton was particularly "intrigued by the children's enthusiasm and insight" (p. 141). Conveyance of such emotions would be very difficult using quantitative methods. Walton (2007), on the other hand, was able to identify specific strategies adolescent males used to create meaning from graphic novels thanks to an interpretivist approach involving interviews and focus groups.

Others also mixed interviews with focus groups (Laycock, 2007; Snowball, 2007) in their studies of the use of visual materials in classrooms and libraries. However, focus groups were ruled out in this study as it was hoped individual interviews would provide more detailed personal experiences.

\subsubsection{Research sample}

The target population of this project encompassed all primary, intermediate and secondary schools in Hamilton, New Zealand (Jaeger, 1984). It did not include rural schools or pre-schools, kindergartens or tertiary institutions. Hamilton was chosen because it was representative of many New Zealand cities and because of the proximity to the researcher's base. However, because of time and resource constraints, conducting interviews at all schools was ruled out as it would have been too much of a burden for one beginner researcher (Kemper, Stringfield, \& Teddlie, 2003). 
Therefore, purposive sampling (Gorman \& Clayton, 1997; Pickard, 2007) was used to determine which teachers and librarians were interviewed. Purposive sampling was particular relevant to this project as it identified information-rich cases which could be examined in depth in order to provide greater understanding of the phenomenon (Pickard, 2007). However, because of the small sample size, the results were not representative of the full population, and therefore it was not possible to generalise (Kemper, Stringfield, \& Teddlie, 2003).

Teachers and school librarians were chosen as the interview subjects because their work as educators puts them in a prime spot to observe students' responses to visual learning materials, and therefore their experiences would be a rich source of data on the topic (Gorman \& Clayton, 1997). Interviews were conducted at schools in an environment in which interviewees felt comfortable to talk and at a time convenient to them.

\subsubsection{Pilot study}

A pilot structured interview with one teacher was conducted to ascertain any problems or ambiguities with the method (Pickard, 2007). The aim was to improve the reliability and validity of the instrumentation. One teacher was chosen participate in an interview and identify any concerns.

The pilot study raised some important points. Firstly, some of the questions were repetitive and covered the same ground as previous questions. Therefore, the question set was refined in order to eliminate this problem. Secondly, the pilot study showed that the questions were at times very general and did not solicit the in-depth personal experiences the researcher aimed to uncover. Therefore, new questions were introduced which sought to explore specific personal experiences in more detail. 


\subsubsection{Limitations and delimitations}

Sample

The study was limited to the geographical area of Hamilton City in the Waikato region of New Zealand. The sample size for this project covered only one geographical zone and therefore was too small to be statistically viable for generalising beyond the project scope (Kemper, Stringfield, \& Teddlie, 2003).

Initial investigations into the presence of graphic novels in Hamilton school libraries revealed the sample pool for this project was smaller than expected, with many schools indicating they either did not have graphic novels in their libraries, or that they had only had a few in the collection. The response rate from schools identified as having graphic novel collections in their libraries was $58 \%$, with several of these indicating they were unable to help. Of this, the number of teachers who volunteered was lower than desired, with several schools nominating librarians to participate. Therefore, the project was extended from exclusively teachers' experiences in classrooms to include librarians' experiences as well. This allowed an acceptable number of volunteer participants to be found. Three teachers and three librarians were chosen. However, because of the limited sample pool, and the small size of the study, it is not possible to generalise beyond the project scope.

Schools at all age levels were included in the research where possible to identify any patterns between type of school and the use of graphic novels as learning resources. Schools without graphic novel collections were excluded as this research was only investigating the current adoption and use of graphic novels.

\section{Bias}

Qualitative research is subject to personal interpretation and therefore some degree of bias was present both by the researcher and teachers and librarians to the subject matter (Creswell, 2009). The researcher's view on graphic novels 
may be coloured by her experience in public libraries, where the popularity of graphic novels has taken off in the past few years. However, the researcher is not a graphic novel reader and has not been exposed to graphic novels in education before entering the library profession. Bias may be present with participants' responses due to the fact the schools who took part have chosen, rather than rejected, graphic novels as a resource, and those who volunteered could be viewed as biased in favour of graphic novel use in schools, merely because those most likely to volunteer are those who have developed a personal connection with graphic novels.

Of the six schools who participated, five had a decile rating of seven or more, with two rated as decile 10 schools. This indicates the sample is not representative of all schools in Hamilton, but is biased in favour of schools in higher socio-economic areas. This may be indicative of the school's ability to afford graphic novels, as funding may be more readily available for library collections in schools in higher socio-economic areas.

\section{Exclusions}

This research explored only the extent to which graphic novels were used as a learning resource within schools and teachers' and librarians' experiences with graphic novels. It did not cover students' personal interaction or responses to graphic novels.

\subsubsection{Ethics}

The researcher firstly gained ethics approval to conduct interviews from the Victoria University's Human Ethics Committee. Following this, written permission was sought from school principals to talk with teachers or librarians (see Appendix A). Research aims were fully explained (see Appendix B) and consent forms (see Appendix C) gathered from participants. Any information identifying participants was excluded from the final report to ensure confidentiality. Interview data was entered into password-protected computer files which only the researcher could access, and any printed 
material was stored securely to ensure information was not misused by others. Participants were sent a written copy of summary research findings at the completion of the project.

\subsection{Data analysis techniques}

Data analysis was done using content analysis of the interview data (Babbie, 2008; Creswell \& Plano Clark, 2007). Data was coded in three ways using descriptive, topic and analytical coding to identify patterns and themes (Richards, 2005). The researcher:

- recorded interviews on an digital recording device and took written notes;

- transcribed the interviews into a word processing document (Cresswell, 2009);

- explored the data by reading through responses and identifying themes in order to develop a preliminary understanding of the results (Cresswell, 2009);

- coded data using descriptive coding to investigate the attributes of each interview case (Richards, 2005);

- coded data using topic coding (Richards, 2005) which applied predetermined and emerging codes (Cresswell, 2009) to phrases, sentences and paragraphs in order to group evidence in a way that reflected the research questions identified at the beginning of the project and other themes which emerged during exploration of the data;

- coded data using analytical coding to interpret and reflect on meaning within the data in order to address the research questions and overall aims of the project (Richards, 2005);

- Wrote a summary and conclusion of the findings of the research project.

\subsection{Reliability and validity}

To increase the reliability and validity of results, the researcher:

- read through and checked transcripts on several occasions to ensure there were no obvious errors (Cresswell, 2009); 
- ensured consistency when coding data by constantly checking the meaning of assigned codes had not shifted as analysis was done (Cresswell, 2009);

- used self-reflection to clarify any bias on the part of the researcher (Cresswell, 2009);

- presented negative and discrepant information in the final report that ran counter to identified themes (Cresswell, 2009). 


\section{Findings}

Data were collected during the month of May, 2009 from six semi-structured face-toface interviews with three teachers and three librarians from Hamilton primary, intermediate and secondary schools.

\subsection{Overview}

To what extent have Hamilton schools adopted graphic novels as a learning resource and how successful have they been as a visual learning tool?

This research project found the adoption and use of graphic novels as a learning tool in Hamilton schools was an emerging phenomenon. They were being adopted by schools, but only used as a learning tool to a limited extent. The mean for participants' use of graphic novels in schools was 3.16 years, while the mean for the number of years working in schools was 11.3 years (see Figure 1 below). The median was two years and 12 years respectively. This showed that graphic novels were a recent arrival on the scene for participants, many of whom had been involved in education for an extended period of time. Two participants could be viewed as early adopters, with 12 years' experience between them, while the remaining four had only recently adopted them as a resource, with either one or two years' experience each. These figures indicated the use of graphic novels in schools was a relatively new phenomenon in Hamilton, and that the schools involved in this project may be considered as leading the way in the adoption and use of graphic novels. 


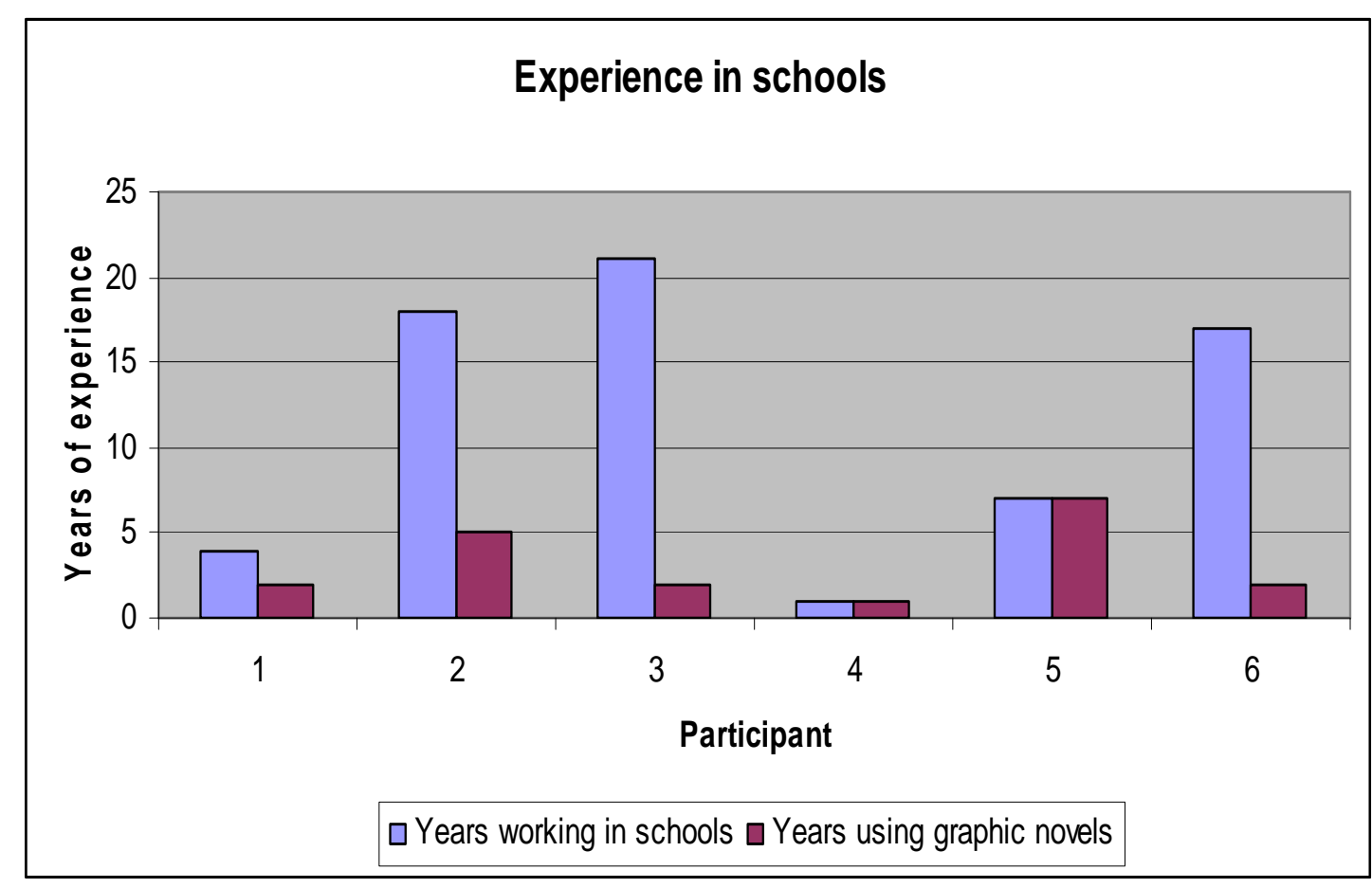

\section{Experience in schools}

Mean $=11.3$

Median $=12$

\section{Experience using graphic novels}

Mean $=3.16$

Median $=2$

The study found there were several factors influencing the extent to which graphic novels were adopted. Influences such as library networks, professional development opportunities, and the inclusion of graphic novels in university teaching courses were encouraging the use of the format and helping provide formal recognition of graphic novels as a legitimate learning tool. Libraries were found to play a key role in providing momentum for the adoption of graphic novels, with three participants referring to the influence libraries and library networks had on their motivation to select graphic novels for their schools.

Participant one: "With the library network system within the schools, we have library network meetings with the National Library and one of the topics was graphic novels." 
Participant three: "Well, the librarian actually said we are going to a workshop, do you want to come along. And I didn't realise so many schools were into graphic novels and we thought that's a good idea."

Participant five, a teacher who made the first moves to source graphic novels, also received "strong support" from school librarians:

“Our librarians were fabulous. Though they didn't quite understand the level of passion that some readers have, they were still happy to get it in, in as much as they were happy to get in The Whale Rider, or happy to get in Wild Swans for older readers."

Two participants referred to professional development opportunities, such as courses outside their schools, which were promoting the use of graphic novels.

Participant two: "I did a course with Wayne Mills about using graphic novels in the school. So he is going around the country promoting the use of graphic novels and giving lots of resources for teachers and ideas for teachers to use."

Adding to this formal professional development, participant four commented on the inclusion of graphic novels in teaching courses at university:

"I had a lecturer ... introduce me to the use of graphic novels in a level two English course at university ... University lecturers think it's a great idea, great idea."

The study also found the sourcing of graphic novels was another factor facilitating the adoption of graphic novels. Quality educational graphic novels were becoming easier to source as more publishing companies produced more graphic novel literature which was suitable for school-aged children.

Participant two: "But there is just a wealth of new books coming, the benchmark is just going higher and higher I think ... [it's] much easier 
than it used to be [to source them] ... And they are producing them now to be appropriate for a wide age range."

Participant six: "Yes, they are more readily available ... I guess if they [publishing companies] see the demand, they'll provide."

However, the perception that graphic novels were full of violent and sexualised content was still present in some schools and was limiting the extent to which graphic novels were adopted at these schools. While participant three commented that there were more educational graphic novels coming out, this was offset by the view that the school was still struggling to find graphic novels that were "non-offensive":

"We don't have very many yet, because it's very hard to find decent ones ... we didn't just want them for entertainment value. We also wanted them for, you know, to encourage their critical thinking, and actually have some themes that they could think about. So that was the hard part."

This was also reflected in participant six's comment:

"Drawbacks for me would be watching the violence, because graphic violence is much clearer than written, the written word. And so once again, I am very careful with what we choose."

While three participants particularly mentioned the Nancy Drew and Hardy Boys series as resources they had, and which children enjoyed reading, participant three's perception of these books was vastly different:

"I have looked at the Hardy Boys and the Nancy Drew graphic novels, but we wouldn't be able to have them in our library, because the Hardy Boys look as though they are on steroids, and Nancy Drew looks like Barbie. You know, and it's very, very sexualised. And that's not suitable." 
Another factor limiting the extent to which graphic novels were adopted by schools was funding. Three participants listed funding and the cost of providing graphic novels as an influencing factor on their use.

Participant three: “And if you do get a good one, like 300AD, it's $\$ 70$. You know, and if you are working on a budget, it's quite a steep price to pay. So that's the pity - good graphic novels are expensive."

The study found the extent graphic novels were used in classrooms was limited by age. Schools were adopting graphic novels as a classroom resource for intermediate and secondary students, but as a library resource only for younger students. The only subject in which graphic novel modules were taught was English. Participants one and six both ran library activities at their primary schools, while participant two, whose school has students from Year 1 to 8, ran a library activity while another teacher in the school ran a classroom programme. However, the classroom programme was for older students at the school:

"And we have featured graphic novels as one of the weekly features. I don't do it every year. About every other year. But meanwhile the teachers, the Year 8 teachers, someone's doing it most years up in the classroom."

The remaining three participants were all involved in intermediate or secondary education. Participants four and five both used them with middle year levels.

Participant five: "We have a set prescription with our syllabus and curriculum, and so, in the junior school, particularly, we'll use them in Year 9 and 10, and not in the senior school, unless it relates directly to an area of the curriculum, but not deliberately."

While participant three was targeting all senior students from Year 9 upwards:

"At the moment, we're using them, well I use them, sometimes for visual literacy and for levels, for Year 11 to 13 as practice for their 
external, because they get a visual text ... And with Year 9 and 10 we use them basically to encourage kids who are reluctant readers to actually read, and that works quite well."

While the study found the adoption of graphic novels in schools was in the early adoption phase, the success they have had as a learning tool was more evident. Participants had mainly positive experiences using graphic novels in schools. One of the major themes identified in the data was the impact graphic novels had on students' engagement and enthusiasm. All six participants raised this theme during interviews.

Participant one: "They bring enthusiasm to children that before wouldn't have had any ... It's a really good buzz, a really good vibe from the children."

Participant four: "But within the time I was with them, from the beginning of the module to the end of it, the engagement went through the roof with some of them"

Participants particularly experienced successful outcomes when using graphic novels with reluctant readers and boys, who responded particularly well to interaction with the format.

Participant one: "It is predominantly the boys that are into the graphic novels."

Participant three: "The reluctant readers [respond most positively]. The boys are more reluctant than the girls."

Participant six: "Benefits include reading mileage for reluctant readers - they sometimes look like a fat book, but are easy to read."

The librarians also noted the books' popularity with all students, with all three commenting that they were never on the shelves. 
Participant one: “And again, the graphic novels, they're not on the shelf. They're never on the shelf."

Participant two: "The most popular reserved book at the minute is a little wordless book that has about 100 images per page called Mister $O$. And even though we have had the book for a year, there's still 19 reserves on it."

Another theme identified in the study was the benefit participants felt came from linking visual and written language, as all six rated visual resources very highly.

Participant one: “And I think that's too where graphic novels will help because they've got pictures, so you can look at the words, and even if they read the words, the pictures will reinforce it, so they are instantly getting more success, and the reading flows."

Participant four: “They're an up-to-date medium, bang up-to-date medium, that combines visual language and written language. And that's really important."

The study also identified the presence of a conflict over whether graphic novels stimulated further interest from students in literature, reading and libraries. Three participants felt they were successful at this.

Participant one: "I think they make the library more accessible, just that the children want to come in and access the library."

Participant three: "I've got a Year 12 kid who's dyslexia, he really struggles with reading. And we've got Stormbreaker, the graphic novel ... Well, he's read the graphic novel Stormbreaker, and he's actually gone and read other Anthony Horowitz books. Books, the actual text ... Because I saw him, I've never seen Daniel read and the other day he was sitting reading a book. So that's good." 
However, two participants warned this was not always the case.

Participant two: "Maybe in that whereas you might have persuaded some children to read a longer novel before, they' re happy to go with the graphic novel and forgo the novel."

Participant five: "If I were to observe a junior class as a whole class, I would say no, I wouldn't say it stimulates them to read different texts and a wide range of graphic novels."

The study found factors which were viewed as drawbacks to the format included perceived poor reputation, poor physical quality of books, and as mentioned earlier, content and cost concerns.

Participant four: "There are some people around who are literary snobs, who would look down their nose at them ... In fact, the only negative response I got was from another teacher. And it was a lookdown-your-nose, scornful, "oh, so you're the guy who is teaching Batman, are you?"."

Participant five: "I don't think many staff members are going to champion more funds going towards graphic novels in favour of their favourite short stories and anthologies, to my own disappointment."

Participant six: "[They] bend in bags. Some of them are not well bound."

But these factors were outweighed by the benefits as viewed by participants. Overall, this study found teachers' and librarians' experiences with graphic novels in schools were positive. Participants were optimistic and enthusiastic about the potential graphic novels had as a learning tool, and all six participants recommended they continued to be used in schools in future or be adopted by those schools without them. 
Participant one: "We're not planning on getting rid of them anytime soon. I think if that anything, this sort of thing coming out shows that people are recognising there is a need for them, and that they are popular and the success that people have with them generally speaks for itself, if people are reading the literature on graphic novels."

Participant four: "I don't think you are dumbing down texts. But they are a very successful, massively commercially available, type of text. So if we are not teaching this, then we are denying them a very modern, plausible text to read."

Participant five: "So I think it is absolutely necessary all schools in New Zealand have a graphic novel shelf somewhere, not exhaustive, but there."

However, participant three, while recommending other schools adopt them, tempered that with a warning that schools needed to be selective and concentrate on quality graphic novels that "will hook them into quality reading, that will increase their critical thinking, that will elevate vocabulary and sentence structure and actually educate the kids".

\subsection{Visual resources}

\section{What value do teachers place on visual resources in the classroom?}

The study found that both teachers and librarians valued visual resources highly, with five out of six participants stating they were "very" or "extremely" important in schools today. Participant five was aware of how teachers needed to "meet the different areas of multiple intelligences" and acknowledge the various learning styles. This reflected the same principles of the Multiliteracies Theory put forward by the New London Group (Cazden et al, 1996). This teacher spoke often of the need to cater to visual-spatial learners: 
“Our weak learners, particularly, need visual texts, if they haven't captured the learning at an earlier stage, as well as our visual-spatial learners, who are either dyslexia or struggle with letter symbols as opposed to picture symbols ... I think educators are becoming aware of the need to identify different types of learning and meet that need, as I mentioned earlier before with the visual-spatial learners who think primarily in terms of pictures, as opposed to only having a logicalsequential sort of thinking."

While the remaining five were not consciously aware of multiple literacies, they did recognise the need to address and cater to visual literacy in their classrooms and libraries, noting young people's close association with visual resources.

Participant four: "Visual language is one of the major three strands of the English curriculum ... There is a large emphasis on it now. People are really, schools, teachers are really putting an emphasis on it, studying things like advertisements."

Participant six: "Data is received visually these days, a visual society, digital screens - illustrations support young readers."

Four participants noted that the emphasis on visual resources had increased during their careers, as the awareness in schools of different learning styles increased and the need to cater to more visual learners became apparent.

Participant two: “Absolutely. It's become a lot more featured, focused on. ... Definitely in education, as well, of library staff and teachers, there is more of an emphasis [on visual resources]."

Participant three: "Because there is much more emphasis on using equipment such as the data projector, power points, things like that. Which when I started off teaching, you had your overhead and that was your visual. Now you've got DVDs, you've got videos, you've got 
orals, you've got the data projector. You've got, you know, a far wider variety of options."

This appears to be driven by students' connection to popular culture and visual language, with all six participants commenting on this influence.

Participant five: "I think our current New Zealand culture is one of over-saturation of visual images, from film to television to multimedia applications through the internet and mobile devices like cell phones. I think it's swung the other way and we're heavily influenced by visual language."

Participant six: "Children are asking for items and that, that fall in that category because they are attuned to visual learning, to technology, TV, games."

However, one teacher noted that students were struggling with interpreting visual images and combining visual and written language to determine meaning from a text, and required guidance in order to overcome these issues.

Participant three: "They actually struggle. They actually struggle to sort of, they might say "oh this is very nice and good", but they really struggle to bring the text and the picture together sometimes ... And then once you give them prompts, they do a lot of the time get it."

A second pointed out that there were reluctant readers of graphic novels who struggled with the visual texts.

Participant five: "In as much as we'll have a reluctant reader of straight text on paper, we have reluctant readers of graphic novels. And I think for the same reasons that a visual-spatial primary learner will engage graphic novels easily and with coherency, so too will a person who can read a novel and chapter book struggle with graphic novels." 


\subsection{School programmes and activities involving graphic novels}

\section{How are teachers and school librarians introducing graphic novels into school programmes and activities?}

The study found that schools were using graphic novels in both library and classroom activities. As stated above, the classroom programmes were aimed at older students, while the library programmes and activities were for younger, primary-aged students. In all three classroom programmes, and in one library programme, graphic novels were used in an individual module where they were the focus of that module. In the other two libraries, they were used as a part of wider activities emphasising reading skills and reading enjoyment.

Of the classroom programmes, the study found the only subject that incorporated graphic novels was English. Within this subject, graphic novels were used to highlight varying educational concepts, such as plot, characterisation and authorship.

Participant four: "There was enough in it for Year 7 and 8 students.

They're quite advanced students, so I could push them to look at concepts like author, you know, who is the author of this, look at character, characterisation, things like that. I was looking for something that incorporated all of the major structures of an English text and that graphic novel gave me that ... I've found it easy, just as easy to factor in literary structural context, issues, lessons, author, point of view, characterisation, all of that stuff, plot, it's all there, themes, you know."

All of the units taught in classrooms incorporated visual literacy elements in some way.

Participant three: "We first go into all the visual literacy about techniques, colour, lightings, dialogue, the layout, things like that." 
Participant four: "What I would do is sometimes, I would use an overhead projection and I'd have the speech bubble but I'd have blocked out the words. So they would have to try and anticipate from the visual language what's happening in the picture."

The library activities ranged from simply highlighting new books to a formal threesession programme for reluctant readers and their parents. Two focused on the reader, while the third focused on learning about graphic novels as a format.

Participant one: "Well, one of the programmes that I was thinking of, was we have a programme called Reading Together, which is basically for reluctant readers ... and it's basically encouraging the children to read and find reading enjoyable."

Participant two: "We have featured graphic novels as one of the weekly features ... One of them for example, is making an $\mathrm{A}$ to $\mathrm{Z}$ of comic book characters, and the kids absolute love that. And another one is giving them all these different terms, things like plewds, which are the little droplets that appear around a character's head when he looks as though he is about to faint. Swalloops would have to be my favourite, where there's the wind-up for a punch. By giving them these words they can look in graphic novels and comics for them."

The target audience of the activities using graphic novels was split almost evenly into two groups, all students and reluctant readers. Three participants ran activities aimed at all students.

Participant four: "But not really targeted at a particular group, because the aspects of the text that we were looking at, I think appealed, there were enough to appeal, enough aspects in that to appeal to all students"

Another two ran activities particularly for reluctant readers. 
Participant six: "Our low readers ... So right from the beginner reader, through to the reluctant, also high interest with the older children who are perhaps not picking up novels.”

The final participant used graphic novels in two activities, firstly for a visual literacy unit for all students, and secondly to encourage reluctant readers to read.

Participant three: "At the moment, we're using them, well I use them, sometimes for visual literacy and for levels, for Year 11 to 13 ... And with Year 9 and 10 we use them basically to encourage kids who are reluctant readers to actually read, and that works quite well."

\subsection{Types of graphic novels selected for use}

\section{What types of graphic novels are teachers and school librarians using?}

The study found that the majority of schools had a wide range of graphic novels, with four out of the six participants saying their schools included most genres such as superheroes, classic titles, myths and fairytales, general fiction, and non-fiction.

Participant one: "I mean, we have a whole lot of non-fiction as well, I shouldn't forget about that. The likes of the story of Helen Keller, and Levi Strauss jeans, and Kodak camera, all of the learning, the nonfictional section in graphic novel, which is a real hit."

Participant two: "We've got a wide range. Very popular are the Hardy Boys and Nancy Drew, so they enjoy the detective stories. They like the traditional superheroes. But we also have a good range, and they're very popular as well - one boy borrowed Kidnapped by Robert Louis Stevenson yesterday - of classics. And at the minute, I have been enlarging the section of mythology, myths and legends, because there are some superb versions of those currently." 
Participant five: "I try to find mainstream graphic novels that are accessible and familiar to the general population, for example, Superman, Spiderwoman, well she's not as popular, but also teen character novels, such as the $X$-men."

Of the remaining two, one had a wider range of novels than the second, who was very selective about which graphic novels were chosen. Both these participants were selective due to their school's vision and principles.

Participant three: "It's because of the philosophy - the overall spiritual tones of it."

Participant six: "It has to fit with our curriculum."

Both raised concerns over the content and were worried about the violence and sexuality that was associated with graphic novels.

Participant three: "Well, from our point of view, some of the graphic novels that we've looked at weren't suitable, you know, because a lot of them hinge on violence and sexuality."

Manga was noticeably absent, with only participant two mentioning this genre, but dismissing it as inappropriate for her school.

"A lot of manga is more suitable for high school because of the relationship content and the level of violence in it." 


\subsection{Benefits of using graphic novels in schools}

\section{What benefits do teachers and librarians feel graphic novels bring to schools?}

As mentioned earlier, all teachers and librarians interviewed felt graphic novels were beneficial for schools. While several drawbacks were identified, the study found participants felt these were outweighed by the benefits they had witnessed in their experiences. Participants were positive and enthusiastic about the potential graphic novels had as a learning tool. As previously mentioned, a major benefit identified in this study was the impact graphic novels had on students' engagement and enthusiasm. Three participants mentioned personal experiences which highlighted the engagement and enthusiasm shown by students.

Participant one: "He's [Ben Ten] very popular ... we had a queue at lunchtime when I announced I'd be putting them out on the shelf."

Participant three: "I've had one kid, Josiah, who keeps telling me: "I don't like reading, this book is too fat". He actually comes into the library lunchtime to read Obelix ... One lunchtime he sat there the whole lunchtime reading Asterix and Obelix, and we were thinking oh well at least he is reading, which is good."

The visual nature of graphic novels, and the perception that they were a modern medium, appealed to students, and this was seen as a major benefit by five out of the six participants.

Participant two: "[Students] enjoy looking for the story and seeing where the story is going. They also enjoy, and those that are particularly well done, the use of perspective, that one minute you are looking from a bird's eye point of view and the next minute you're face to face with the character. They love that." 
Participant six: "Visual appeal encourages a beginner reader to pick it up and have a go ... For those that are artistically inclined, they convey meaning, expression, setting - visually."

Another major benefit identified in the study was the ability of graphic novels to help students overcome barriers to learning by offering something different which can also challenge them.

Participant one: "But if the child's reading a book that is too difficult, then they not having success, and then they don't enjoy reading. They find it a struggle, and they just don't enjoy it at all. So that's where graphic novels have been absolutely wonderful, because you can get a graphic novel that has lots of pictures on the page, it might only have three little snippets of paragraphs, but it's enough that they don't feel they are opening a book covered in text when they don't know where to start. And once that gets the ball rolling, they just grow in confidence."

Participant four: "There was enough in it for Year 7 and 8 students. They're quite advanced students, so I could push them to look at concepts like author ... Certainly as an introductory text, kind of text, they work very well with youngsters who are good readers anyway. It's a different kind of text they would want to get into."

As mentioned earlier, there was conflict over whether graphic novels stimulated interest in literature, reading and libraries. Three participants said they assisted students to move on to other types of reading.

Participant one: “And that's where the graphic novels section comes into its own, because we'd say to people, and because we do have quite a wide range, there's generally something, and you can sort of go off on a tangent from there, you know, "there's the chapter books that will flow on from this" and that's a bit of a starting point." 
Participant six: "They expand the collection for the children that would otherwise maybe not voluntarily choose a book or go to the section of novels, well there will be some in there now."

However, two felt they were not assisting students to move on to other types of texts or more challenging reading.

Participant two: "Maybe in that whereas you might have persuaded some children to read a longer novel before, they're happy to go with the graphic novel and forgo the novel."

Participant five: "If I were to observe a junior class as a whole class, I would say no, I wouldn't say it stimulates them to read different texts and a wide range of graphic novels."

Concerns were also raised over the perceived reputation of graphic novels, with three participants commenting there was a stigma attached to the format inherited from earlier comic book critics.

Participant three: "But in general graphic novels don't have a good reputation because you equate them with - very often people don't know the difference between comics and graphic novels ... But very often it's equated with comic books, as, you know, trash."

Participant five: "Graphic novels are welcome amongst the other English resources, but rather as a casual visitor, rather than a valid family member of literature. I think there is still a very strong stigma attached to the way graphic novels are either created or used in classrooms."

But this was offset by four of the participants commenting that this reputation was changing for the better. 
Participant two: "I think that they were looked down on for a long time. Comics were inferior. Tintin and Asterix are classic ... But other forms of comics have been not given the recognition that they deserve and that they are now getting. But I think it's just happening in the last three years in New Zealand that people like Jeremy from Gotham Comics in Auckland and people like Wayne Mills, going around the country giving teachers professional development and how to use comics, that they're getting a lot more credibility."

Participant four: "University lecturers think it's a great idea, great idea. The English department [at the university] use graphic novels themselves for university courses, so that's, you know, there's no higher tick in the box for that."

As noted earlier, other drawbacks included poor physical quality, the cost of the books, and that some content was inappropriate for young people.

Participant three: "So we've gone to great lengths to get some good ones ... The quality and the content, yes. And that's what we look at for our, I know [our librarian] does. She looks at the quality and the content. Everything is read before we put on our shelves."

Participant five: "But within that, there're some restrictions with what this department will deem as acceptable, for example, Watchmen would not be acceptable. I think it raises too many questions in a lesson over a period of time to be able to answer ... At times, the drawback can be that the narrative is weak in favour of a visual spectacular - there is that danger." 


\subsection{Changes to students' skills and attitudes}

\section{What changes in students' skills and attitudes have teachers and librarians observed when using graphic novels?}

The study found that while both teachers and librarians had noticed positive changes in the attitudes and skills of students who were reading graphic novels, this was not the case with all students. Changes in skills noted by participants included improved vocabulary, reading, and searching skills.

Participant one: "What I see in the library is that their reading skills are changing. They are more interested in reading. They are more interested in the library, which has the flow-on effect that they are more oral."

Participant three: "Sometimes you can see a difference in their vocabulary. Depending on the text, like sometimes even Asterix and Obelix extends their vocabulary because it's so basic."

Participant six: "It also helps them with their searching skills, because we then show them how to find more. We bring them to the computer and we tell them how to search for more. And that's the beginning of life skills, information skills."

In particular, participants commented that students were experiencing improved responses to the text, and were producing better work because of this.

Participant three: "I had a Year 12 girl last year get The Raven, and she did a brilliant reading response about fear and death and yeah, that was fantastic."

Participant four: "I had a range of activities that we did afterwards - we re-wrote the story from a first-person point of view. So there were some great, great pieces of work done there." 
Positive changes seen in students' attitudes included an increase in enthusiasm for reading, as well as for using libraries, and more confidence, which led to students being more vocal with their thoughts.

Participant one: "I think they make the library more accessible, just that the children want to come in and access the library ... They are a lot more vocal, a lot more, a lot happier in the library ... One of the things they will do, is tell me about the book they've read, which of course, they never used to do before. They're so excited about it."

Participant two: "There's possibly more enthusiasm about borrowing a book from the library, from a librarian's perspective. And, as I say, there are a lot of them on reserve, that kids are waiting for and eager to read. And they get really excited when it's their turn to have it."

However, not all students displayed the above changes in skills and attitudes, and in general did not appear to have any interest in reading graphic novels.

Participant two: “There are some who aren't interested, yes. We had a boy who left at the end of last year who hadn't seen a movie before the age of 10, and he's not interested in seeing movies of books, and he wasn't interested in reading graphic novels. He likes to create his own pictures in his mind."

Participant three: "They actually struggle to sort of, they might say "oh this is very nice and good", but they really struggle to bring the text and the picture together sometimes ... There are kids who don't like the pictures ... Very often they are kids who prefer novels."

Participant five: 'In as much as we'll have a reluctant reader of straight text on paper, we have reluctant readers of graphic novels ... I know that graphic novels are not for everyone, and I can see it'll bring the same sort of tensions that Shakespeare does to other reluctant readers." 


\subsection{Student responses to graphic novels in schools}

\section{Do particular groups of students respond better to graphic novels than others?}

The study found that the students who responded the most positively to the use of graphic novels in schools were boys and reluctant readers.

Participant two: "But they've definitely printed way in excess that will appeal to boys. I think with everyone talking about boys and reading, that in the book publishing industry in general, and in the writing, there has been this huge sway to writing and publishing things for boys ... And it's, yes, the reluctant readers, they are just such a bonus for reluctant readers."

Participant four: "But also they worked well with youngsters who weren't keen readers, who ummed and aaahed and messed around in the library and things like that."

Participant five: "Stereotypically, I would say that ethnically that the Maori and Polynesian boys seem to respond more fiercely and quickly to superheroes than perhaps the other ethnic groups. Why that is - I'm not sure."

However, while boys were the most enthusiastic about graphic novels, this study also found girls responded well to the format, with five participants experiencing positive responses from female students.

Participant one: "In fact one of the girls we've got on the course at the moment is very big into picture books, visual books."

Participant four: "And I suppose, maybe surprisingly if you look at a Batman graphic novel, some of the works that the girls produced were fantastic, they really were." 
Also mentioned, but to a lesser degree, were visual learners and English as a second language (ESOL) students. Three participants raised the former in their interviews, while two talked about the latter.

Participant five: "The boy who is primarily a visual and a spatial learner, who thinks primarily in pictures and space and less in words and sequential ordering of teaching and learning [responds positively to graphic novels].

Participant six: "I haven't mentioned yet ESOL students and international students. We had a group of Japanese students stay. Well, they're very good for them, because with very little English they can see the story. And English as a second language for our students, it just helps them. It's like a bridge." 


\section{Discussion and analysis}

\subsection{Role of libraries in advocating for graphic novels}

One of the most important findings in this study from a library perspective is that libraries appear to provide the driving force behind the adoption of graphic novels in many schools.

Participant two: "I wouldn't be surprised if you find that the schools that have them are members of the School Library Association, the librarians are. Because they're always talking about what's new, and where do we go from here, and information literacy, and there's a huge amount of information literacy opportunity in graphic novels ... and therefore, it's the librarians who are generally driving what is happening, I think you'll find. So if you talk to teachers, I think a lot of it will reflect back on whether the library has picked up the ball or not."

Comments like this one indicate teachers are often realising the potential of the format only after librarians have taken an interest in them. The implications of this are huge for the future use of graphic novels in schools, as libraries hold the key to unlocking the potential of graphic novels in schools. By guiding teachers and showing the benefits graphic novels bring to learning, in particular in relation to boys and reluctant readers, librarians can change the way graphic novels are perceived in educational circles. Only then will the historical stigma attached to graphic novels begin to diminish.

This finding is not surprising in light of overseas literature which shows librarians such as Foster (2004), Gorman (2003), Kan (2003), Lyga and Lyga (2004), Searchay (2004), and Weiner (2001) have been keen advocates for graphic novels for more than five years and have been vocal in their support of the format. Their combined voice is helping change the perception of graphic novels around the world, and may account for the positive reputation generally found in this study. The more library advocates 
spread the word, the more the format will become accepted in schools today by their educational colleagues. Without the support and backing of librarians, schools may fail to recognise the potential graphic novels have as an educational learning resource.

\subsection{Acceptance as an educational learning tool}

The results of this study are encouraging for the future of graphic novels in schools. While it is still an emerging phenomenon in Hamilton schools, the signs are positive that New Zealand is not too far behind the rest of the world in recognising the potential of the format for educational purposes. When put in context of recent overseas literature, this study shows New Zealand is reasonably placed for the speed at which schools are adopting educational programmes involving graphic novels. Of the studies identified in the literature review, the earliest was 2003 when Norton looked at the use of Archie comics and Albright and Walsh investigated visual culture in the classroom. In the six years since then, many other studies have been conducted, with many only done two years ago (Andera, 2007; Bergin, 2005; Cho, Choi \& Krashen, 2005; Fitzsimmons, 2007; Frey \& Fisher, 2004; Lamanno, 2007; Laycock, 2007; Ranker, 2007; Schneider, 2007; Walton, 2007). The participants in this study adopted graphic novels between one and seven years ago, with a mean of 3.16 years, illustrating they are keeping pace with moves in overseas educational circles. This is promising as it shows New Zealand educators are aware of overseas developments and are implementing them where they feel it is beneficial to do so.

This study has also shown graphic novels are becoming more accepted as an educational learning tool. Highlighting this changing perception is the fact that three of the schools who participated in the study are guided by religious principles. This is important to note as Christian schools have not traditionally been advocates of graphic novels due to concerns over content, which they have viewed as inappropriate and contrary to their values (McNicol, 2005). For these schools to be including graphic novels, and for them to be able to source suitable graphic novels with content to match their educational values, shows that the current situation is different to that seen in the past, and steps are being made to legitimise the format. These schools are recognising the value of visual resources, and as long as they can source quality 
resources which convey the appropriate message, they are happy to adopt graphic novels.

Participant three: "Well, from our point of view, some of the graphic novels that we've looked at weren't suitable, you know, because a lot of them hinge on violence and sexuality. So we've gone to great lengths to get some good ones, like we've got Beowulf, the graphic novel, we've actually got graphic novels on The Heavenly Man, which is a Christian novel, we've got The Arrival. So we try and get critically acclaimed ones to actually get the kids, not just to view them as comics, but as text that convey themes and ideas through text and pictures."

This desire to source quality graphic novels indicates the link between graphic novels and inappropriate content is starting to dissolve, and therefore attitudes towards the format are changing. Librarians such as Gorman (2008) and Kan (2003) have long been putting together lists of educational graphic novels for schools to use in their desire to select the right books for their school. This means the barriers to using graphic novels, in particular sourcing quality graphic novels with educational content and the perceived reputation of graphic novels, are being removed, opening up the way for them to be used as a genuine learning resource in schools.

One reason for the improving reputation of graphic novels is that they are being included in professional development programmes and formal teaching practices in universities. This inclusion may be the determining factor which helps other educators recognise the benefits of the format.

Participant five: "And that's where it'll be successful in schools or not, is where people like Wayne [Mills] are allowed to carry on with what they are doing, promoting the genre."

This is good news for graphic novel advocates, as it is lifting the profile of graphic novels, therefore helping schools recognise the potential value of the format for 
education. This also helps increase the validity of graphic novels as a learning tool. However, caution must be applied here, as perceptions are only beginning to change.

Participant three: "But very often it's equated with comic books, as, you know, trash. And that is a mind set that I think we have to change, especially among non-English teachers because it's equated, a graphic novel is a comic, which is not correct."

Participant five: "I think more PD [professional development], as we talked about earlier, needs to occur for teachers, particularly teachers who are not engaged in graphic novels, in as much as teachers who are not engaged in poetry to any depth."

As these participants have noted, awareness needs to be raised among non-advocates before graphic novels will be accepted unreservedly. This awareness will be helped by more empirical studies, such as this one, where the benefits of the format can be published in formal educational channels. As this study has shown, graphic novels can be a useful tool to raise enthusiasm and engagement in students while still catering to curriculum requirements. Graphic novels can also assist students with visual literacy when provided with appropriate guidance from teachers and librarians.

\subsection{Need for balanced collection of resources}

While all teachers and librarians recognised the importance of visual resources, some tempered that with recognition of the need for balance in teaching approaches and collection management in libraries. This finding backs up the Multiliteracies Theory, which emphasises the value of all learning styles, and in particular visual learning (Cazden et al, 1996).

Participant five: "I know that graphic novels are not for everyone, and I can see it'll bring the same sort of tensions that Shakespeare does to other reluctant readers. Again, it's critical and it's absolutely essential that teachers realise this when attempting to encourage reading, 
writing, speaking, and responding to text. To ignore that in a learner will be fatal."

Participant six: "But once again it needs to be a balanced collection when introducing anything to our collection we need to look at the balance of the whole collection."

These comments support the Multiliteracies Theory put forward by the New London Group, which advocates for a variety of resources to reflect different learning needs. Therefore, while graphic novels are a useful resource, they should be viewed as just one part of a wider, all-encompassing approach to education. However, the study findings do illustrate that more emphasis on visual resources in schools and libraries is justified. Librarians can focus on visual resources, not just graphic novels, but resources such as picture books, educational DVDs, and computer software, with the knowledge there is a legitimate need for them in schools today.

As for the types of graphic novels librarians should be selecting, this study has shown a wide variety of both recreational-focused graphic novels, such as superhero graphic novels, as well as educational ones, such as Shakespeare in graphic novel format, is appropriate in order to cater to students' interests. Schools can limit their selection policies as they see fit, but by utilising a wide variety, the ability to appeal to different groups of students is increased, including girls, advanced students and ESOL students. This will help graphic novels cement their place in schools as useful learning tool for all age groups, sexes and learning levels.

\subsection{Impact on students}

The impact on students of using graphic novels in schools is compelling. There are encouraging signs for enthusiasm, engagement, comprehension of visual language, and responses to the text. Students, who otherwise would have been unresponsive, are interested in libraries and reading, are seeking out further reading, and are gaining confidence in educational environments. 
Participant one: "[Students are] definitely gaining confidence. The before and after of the course is marked. There's a big difference."

Participant six: "I believe that they're a way of expanding the enjoyment of reading for certain children and that will continue. I believe that they are a bridge to get them into reading."

Comments such as these must be seen as beneficial to all involved, from librarians and teachers to students and parents. Graphic novels have the ability to break through learning barriers because they are popular with students, appeal to students' visual natures, and are associated with popular culture, thus succeeding where other formats may have failed. This backs up earlier overseas literature which recognised the link to popular culture and the benefits that could be reaped because of it (Albright \& Walsh, 2003; Brooks, 2008; Hughes-Hassell \& Rodge, 2007). Therefore, it is positive to note New Zealand students display similar responses to overseas students.

The study results highlight the success graphic novels can have as an educational tool, especially with boys and reluctant readers, whom this study found to be the most responsive to the format. This finding reflects overseas literature which also highlighted the format's appeal with these two groups (Andera, 2007; Gowing, 2006; Laycock, 2007; Walton, 2007; Welldon, 2005). These authors asserted that associations with popular culture meant boys were more likely to respond to programmes involving graphic novels. This study backed up those findings, and in particular Laycock's (2007) observations that behavioural engagement increased. Boys in this study showed increased enthusiasm for and engagement with the format.

Participant six: "I have seen boys pick up Baby Mouse and read it, take an issue and read it - it's pink - it doesn't matter [to them] ... Yes, the reluctant readers, and boys [respond the most positively]. And if they've had one, they'll ask for more."

While the study found boys and reluctant readers were predominantly the students who responded positively to graphic novels, it is interesting to note that girls and advanced students also engaged well with the format. This finding is not as prevalent 
in previous studies, although Crawford noted the format's popularity with both sexes in a brief study of New Zealand students in 2002. The reason for the previous lack of association between females and graphic novels may be because the majority of graphic novel publishers appear to target male readers. Two participants raised this issue, commenting that girls were struggling to find graphic novels that matched their interests.

Participant two: "So the other ones now that the girls like now, they like the Nancy Drew, we got a couple of Babysitters' Club, we've got Baby Mouse. So the girls like the ones that have feminine storylines. But they've definitely printed way in excess that will appeal to boys. I think with everyone talking about boys and reading, that in the book publishing industry in general, and in the writing, there has been this huge sway to writing and publishing things for boys. Girls will read a lot of them, but I think girls are on the back foot at the minute, that there's not being as much written for girls as there is for boys."

Concern needs to be shown to this finding as failure to cater to the needs of girls may result in the format failing to reach its potential as a learning resource in schools, as educators may view the resource as more suited to boys and reluctant readers and therefore restrict its use to these groups.

Another group of students identified in this study as responding well to graphic novels were ESOL students. This finding reflects earlier research by Cho, Choi and Krashen (2005), Frey and Fisher (2004), and Ranker (2007). However, this finding was not present to the same degree in the present study, as ESOL students were only mentioned as a secondary group to boys and reluctant readers. However, this does show the potential is there to use graphic novels as an appealing and modern resource in New Zealand schools for overseas students learning English.

Participant four also felt advanced students reacted well to the use of Batman as a study text. 
Participant four: "There was enough in it for Year 7 and 8 students. They're quite advanced students, so I could push them to look at concepts like author."

This interest from advanced students, girls, and ESOL students shows the format can appeal to both sexes and all levels of students. This is important because it shows while graphic novels have huge appeal for boys and reluctant readers, the format should not be discounted as beneficial for other groups of students. Librarians need to be careful when purchasing graphic novels that they do not restrict interest in the format to only boys or reluctant readers by narrowing their selection choices to only those genres which appeal to these two groups. By providing resources that can cater to all students' interests, teachers and librarians will expand the appeal of the format and avoid the risk of it becoming classed as a limited resource for only boys or reluctant readers.

\subsection{Tension between access and content}

There appears to be a tension between schools wanting to provide access to graphic novels for students, but also ensuring what they access are quality resources appropriate to the age of students.

Participant three: “The quality and the content, yes. And that's what we look at for our, I know [our librarian] does. She looks at the quality and the content. Everything is read before we put on our shelves. So you have to see, does this actually teach you something? You know, look at the vocabulary, the style, the pictures. Can you actually get something out of it?"

Participant five: "Seems to be that same idea I mentioned before, that any reading is better than no reading. I would want to qualify that, that any decent and intelligent reading is better than no reading. For I would rather have them reading intelligently, than sitting reading passively, or coaxed into reading." 
This differs from previous studies where this tension was not highlighted to a great degree and may indicate that New Zealand schools are more conservative, or may be taking a more cautious approach, to graphic novels than overseas schools. However, while this tension may be limiting the extent to which graphic novels are adopted at the present time in New Zealand, it may prove beneficial in the long run, as it shows teachers and librarians are aware of the impact the wrong type of graphic novel could potentially have on students. If the correct balance is maintained between access and content, then graphic novels will be viewed as an age-appropriate resource with potential benefits, as opposed to a violent and sexually-orientated recreational resource for adults. This latter type of graphic novel will always be present, but by implementing the right selection policy, it need not be an issue in schools.

\subsection{Limitations as a resource}

\subsubsection{Age}

A notable divide exists in the way schools are introducing graphic novels which appears to be based on the age of students. Schools with intermediate and secondary students are using them in the classroom, while in primary schools the focus is on the library, not the classroom. There is also less interaction between senior secondary students in Year 11, 12 and 13 and graphic novels in the classroom, with the most targeted age range those students in Year 8, 9 and 10.

Participant five: "We have a set prescription with our syllabus and curriculum, and so, in the junior school, particularly, we'll use them in Year 9 and 10, and not in the senior school, unless it relates directly to an area of the curriculum, but not deliberately ... At the moment the literacy with graphic novels is set up towards junior school, rather than senior school."

This indicates that schools feel graphic novels are more suitable as a learning resource for students in their early years of secondary education. However, 
participant three also felt there were graphic novels which were better suited to older students:

\footnotetext{
“Then we've got like The Arrival, which is by Tan, which has actually got no dialogue, only pictures, which is for the more sophisticated reader. So we usually, there we target Year 11, 12 and $13 \ldots$ younger age groups struggle with that one, because it is a sophisticated graphic novel. It's really, really good. Very thought provoking."
}

This focus on older year levels as the most suitable students for classroom graphic novel programmes is similar to that seen when analysing overseas studies. Of the studies highlighted in the literature review in Section 3 of this study, the majority involved intermediate or high school students (Albright \& Walsh, 2003; Bergin, 2005; Cho, Choi \& Krashen, 2005; Fitzsimmons, 2007; Frey \& Fisher, 2004; Lamanno, 2007; Laycock, 2007; Norton, 2003; Schneider, 2007; Walton, 2007). Only Andera (2007) and Ranker (2007) investigated primary students' interactions with graphic novels. This implies that there is a general consensus that classroom activities are better suited to older students. Librarians need to take note of this when selecting graphic novels for teachers to use in classrooms, as they will need to be aware of the targeted age group and what resources are appropriate for that group.

\subsubsection{Socio-economic status}

The study involved six schools in Hamilton who had graphic novels in their school libraries and used them as an educational tool. The decile ratings for these schools ranged from four to 10, with a mean of eight and a median of 7.5. Therefore, participants spoken to represent schools in the higher decile range, and consequentially are less likely to be representative of all schools, especially lower socio-economic schools. This implies that graphic novel collections are only associated with schools whose budgets allow for their purchase. This is concerning as it may mean students in lower socio-economic areas are missing out on a viable, beneficial visual resource because their 
schools lack the funding to provide them. Whether this finding is limited to New Zealand needs more investigation as the overseas literature does not focus on this issue in any depth. 


\section{Conclusions and recommendations}

There still exists a tension between graphic novels as a recreational tool and graphic novels as an educational tool, but this tension is easing as graphic novels with more educational content are being published. With many classics, such as Shakespeare, The Owl and the Pussycat, and The Hobbit, now available in a visual format, as well as critically acclaimed graphic novels such as Maus, there appears to be more acceptance of the place of graphic novels in schools, and the first steps towards cementing them as a legitimate visual learning resource are being made. However, the lack of uptake of graphic novels in lower socio-economic schools may be reason for concern, as students may be missing out on the benefits of engaging with a visual learning tool that appeals to reluctant readers and boys in particular.

This study recommends that graphic novels continue to be used in schools, or be adopted by those without them, as the benefits students experience outweigh the drawbacks. It is also recommended that schools adopt a wide selection of graphic novel genres in order to cater to the interests of the wide variety of students found in this study to enjoy interacting with the format. By utilising graphic novels as a learning tool, schools will be addressing the issues raised by Multiliteracies Theory and providing resources that visual learners can relate to and enjoy interacting with. However, this needs to be done in balance with other resources in order to provide a holistic approach to education. Graphic novels have the ability to reach those students who fail to connect with more traditional texts, while also appealing to the wider community of students. This study has shown graphic novel texts can be successfully applied within the New Zealand educational curriculum, and provide a bridge to future learning for struggling students. Schools who fail to recognise the format's ability to overcome barriers to learning may in turn be denying their students a viable and successful learning tool. 


\subsection{Implications for further research}

This study raised several possible research scenarios for the future.

- As this study found the use of graphic novels in schools was an emerging phenomenon, it would be appropriate to do a similar study in five years' time to assess whether this has changed, and if so how. Will more schools have adopted graphic novels and in what ways? Will their reputation as a legitimate learning tool be fully cementing into school curricula?

- The finding that lower-socio economic schools may not be adopting graphic novels because of financial concerns merits further investigation. A quantitative approach of surveying all schools in New Zealand in relation to this topic would be able to assess in much greater detail whether this is an issue which is affecting the adoption of graphic novels in lower-socio economic areas and whether this warrants the attention of educational funding bodies.

- As this study had a wide scope of looking at all activities and programmes in schools, a future research project could look at a specific programme which has introduced graphic novels to students, and assess the impact of that programme on students' skills and attitudes. Students could be assessed before the programme, their interactions monitored during the programme, and then their skills assessed again at the end of the programme. As well as this, students could be interviewed about their experiences and how they feel about graphic novels. This would provide insight into why students show the enthusiasm and engagement noted in the present study.

- As this study found reluctant or struggling readers responded particularly well to graphic novels, a future study could assess the impact the format could have on special needs children. Graphic novels have been shown to break through learning barriers for students in mainstream schools, but whether they could do the same for those students suffering from severe learning disabilities could prove differently and therefore would make an interesting research topic. Special needs 
students' interactions and responses to the format could be monitored and skills assessed before, during and after. However, this type of research would need to be done over an extended period of time, as little difference may be noted if the study period is too short (Lamanno, 2007).

- Girls were found to react well to graphic novels in this study and therefore a future study could investigate the value of the format for all-girl schools. A preliminary investigation for this study found all-girl schools in Hamilton did not have many graphic novels as they felt girls were not interested in them. However, this study has shown this may not be the case. This future research topic could examine girls' responses to the format in depth and investigate whether girls' interest in the format is formed on a different level to boys. This could help allgirl schools determine the value of graphic novels for them and what influence this interest should have on collection management in their school libraries.

- Two participants in this study raised the topic of Maori resources in graphic novel format. A future research topic, which would be important from a New Zealand perspective, could be to assess what visual resources are available to Maori students which highlight Maori subject matter, such as myths and legends, history, ancestry, and social issues. Also an assessment could be done to investigate Maori students' responses to these resources. This would show if these resources foster improved learning practices in Maori and Pacific Island students and whether there is any value in producing similar resources. 


\title{
Appendix A - Cover letter to schools
}

\author{
VICTORIA UNIVERSITY OF WELLINGTON \\ Te Whare Wänanga o te Ûpoko o te Ika a Mãui
}

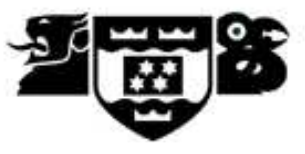

\section{SCHOOL OF INFORMATION MANAGEMENT}

101 Silverdale Road

Silverdale

Hamilton 3216

Friday, May 01, 2009

Principal's name here

School's address here

Dear sir/madam

I am a Masters student in Library and Information Studies at Victoria University of Wellington. As part of this degree I am undertaking a research project examining the adoption and use of graphic novels as a learning resource by teachers in Hamilton schools.

Following a preliminary investigation, I have identified schools in Hamilton that have graphic novels in their school libraries and where teachers may be using them in classrooms as a learning resource. I would like to invite your school to participate in this research project. My aim is to interview teachers who use graphic novels as a learning resource in at least one classroom activity during the school year. This could be any type of activity in any subject area, from a sustained silent reading programme or programme for reluctant readers, to a popular culture module.

Teachers selected to participate will be provided with an information sheet and asked to sign a consent form before commencing interviews. Participation is voluntary. It is envisaged initial interviews will take around one hour. It will not be possible for you or your school to be identified. All material collected will be kept confidential.

If your school would like to participate in this research project and you have a suitable candidate who is willing to be interviewed, please contact me using the details listed below. As the sample pool for this research is smaller than expected, I would truly appreciate any offers of interest. 


\section{VICTORIA UNIVERSITY OF WELLINGTON}

Te Whare Wänanga o te Ūpoko o te Ika a Māui

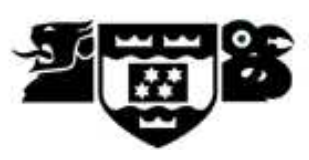

\section{SCHOOL OF INFORMATION MANAGEMENT}

If you have any questions or would like to receive further information about the project, please contact me at:

101 Silverdale Road,

Silverdale,

Hamilton

Email: $\quad$ walkerbryo@myvuw.ac.nz

Phone: $\quad$ (07) 8569323 (home)

(07) 8386842 (work)

0210369604 (mobile)

or my supervisor, Prof. Gary Gorman, at the School of Information Management at Victoria University, Wellington:

Email: $\quad$ gary.gorman@vuw.ac.nz

Phone: $\quad$ (04) 4635782.

Thank you for considering my request.

Yours faithfully

Bryony Walker 


\title{
Appendix B - Participant information sheet
}

\author{
VICTORIA UNIVERSITY OF WELLINGTON \\ Te Whare Wänanga o te Ūpoko o te Ika a Māui
}

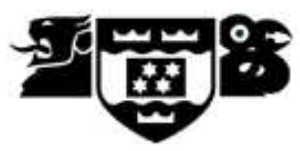

\section{SCHOOL OF INFORMATION MANAGEMENT}

\section{Participant information sheet for a study of the adoption and use of graphic novels as a learning resource in Hamilton schools}

Researcher: Bryony Walker: School of Information Management, Victoria University of Wellington

I am a Masters student in Library and Information Studies at Victoria University of Wellington. As part of this degree I am undertaking a research project examining the adoption and use of graphic novels as a learning resource in Hamilton schools. This project has received ethical approval from the School of Information Management Human Ethics Committee.

The objectives of the project are to examine the current situation in schools in regard to the use of graphic novels as a learning tool in classrooms and to assess how they are being adopted by teachers and used as a learning resource. The results of this project could help principals and teachers assess the benefits of using graphic novels in classrooms and may provide evidence which could influence school library collections in the future.

The principal of your school has given his/her consent for you to participate in this research. Participants will partake in one or more private interviews at which their experiences working with graphic novels in classrooms will be explored using a series of open-ended questions as an interview guide. Interviews will be digitally recorded and notes will be taken during the interview process.

Interviews will take place at a location chosen by the interview participant. In most cases it is envisaged this will be their place of work. It is predicted that the initial interview will take about an hour to complete. Should more information be required, a further interview will be arranged at a time to suit the interview participant.

Participants have the right the check interview notes and amend details if required.

If you would like to withdraw from the project, you may do so without question at any time before the start of data analysis on May 15, 2009. If you choose to withdraw, all data you have provided will either be returned to you, if requested, or destroyed immediately. 


\section{VICTORIA UNIVERSITY OF WELLINGTON \\ Te Whare Wänanga o te Ūpoko o te Ika a Māui}

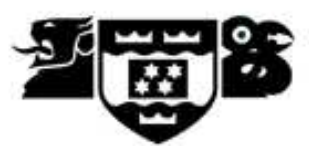

\section{SCHOOL OF INFORMATION MANAGEMENT}

Responses collected will form the basis of my research project and will be put into a written report. It will not be possible for you or your school to be identified. All material collected will be kept confidential. No other person besides me and my supervisor, Prof. Gary Gorman, will hear the recorded interviews or see the written notes made during the interviews.

All computer files containing personal details of participants, notes, and recordings will be stored in password protected files which can only be accessed by the researcher. All physical notes will be stored in a locked case which can only be accessed by the researcher. An electronic copy of the final report will be submitted for marking to the School of Information Management and a printed copy deposited in the University Library. Recorded interviews and written notes will be destroyed one year after the end of the project.

Feedback will be provided to participants through a summary of research findings which will be mailed to participants at the end of the project. The results may be presented at conferences, or published in academic or professional journals.

If you have any questions or would like to receive further information about the project, please contact me at:

101 Silverdale Road,

Silverdale,

Hamilton

Email: $\quad$ walkerbryo@myvuw.ac.nz

Phone: $\quad$ (07) 8569323 (home)

(07) 8386842 (work)

0210369604 (mobile)

or my supervisor, Prof. Gary Gorman, at:

School of Information Management

Victoria University,

P O Box 600,

Wellington

Email: $\quad$ gary.gorman@vuw.ac.nz

Phone: $\quad$ (04) 4635782. 


\title{
Appendix C - Research participation consent form
}

\author{
VICTORIA UNIVERSITY OF WELLINGTON \\ Te Whare Wänanga o te Ūpoko o te Ika a Māui

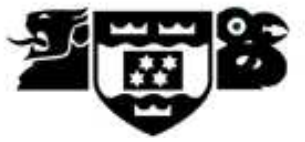

SCHOOL OF INFORMATION MANAGEMENT

\section{Research participation consent}

\section{Project title: Examining the adoption and use of graphic novels as a learning resource in Hamilton schools}

I have been given and have understood an explanation of this research project.

I have had an opportunity to ask questions and have them answered to my satisfaction.

I understand that I may withdraw myself (or any information I have provided) from this project before May 15, 2009 without having to give reasons or without penalty of any sort.

I understand that should I choose to withdraw, any data I have provided will be returned to me or destroyed immediately.

I understand that any information I provide will be kept confidential to the researcher and the supervisor.

I understand the published results will not use my name, and that no opinions will be attributed to me in any way that will identify me or my school.

I understand that the digital recording of interviews will be electronically wiped one year after the conclusion of the project.

I understand I will receive a written copy of my interview notes if I request it and I have the right to alter any comments or change any information I have provided before May 15, 2009 if I feel this is necessary.

Yes, I agree to participate in the above named research project.

Signed:

Name of participant:

(please print clearly)

Date: 


\title{
Appendix D - Guideline interview questions
}

\author{
VICTORIA UNIVERSITY OF WELLINGTON \\ Te Whare Wänanga o te Ūpoko o te Ika a Māui
}

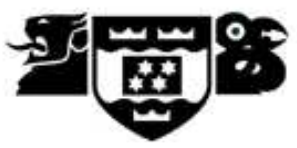

\section{SCHOOL OF INFORMATION MANAGEMENT}

\section{General questions to guide interviews:}

Q1 How long have you been teaching?

Q2 What year levels do you teach?

Q3 What subjects do you teach?

Q4 How important are visual resources to teaching practice in schools today?

Q5 Has the emphasis on visual resources changed during your career as a teacher?

Q6 How are graphic novels viewed in light of other visual resources available? i.e. what reputation do they have in the teaching environments you have worked in?

Q7 How long have you been using graphic novels as a learning resource?

Q8 How often do you use graphic novels as a learning tool in your classroom?

Q9 What made you choose graphic novels as a learning resource?

Q10 In what subjects, programmes or classroom activities do you use graphic novels? Please explain in detail each programme and the part graphic novels play. Are they the main focus or used as background material for activities?

Q11 Are you targeting a particular group of learners when you use graphic novels? If so, why?

Q12 What types or genres of graphic novels do you prefer when selecting them as a learning resource? Why? 
Q13 In your experience, which students respond the most positively to reading graphic novels? Can you give an example of a particular occasion where a student's response was positive and the reason for this response?

Q14 Are there students who respond negatively to reading graphic novels? Can you give an example of a particular occasion where a student's response was negative and the reason for this response?

Q15 In your experience, what changes to skills and attitudes have you seen in students when using graphic novels as a learning tool?

Q16 Have you noticed if students are finding it easier to form understanding or determine meaning from the text when they are using graphic novels as opposed to traditional print texts?

Q17 What benefits do you perceive graphic novels bring to classroom learning?

Q18 What drawbacks have you encountered when using graphic novels as a learning tool?

Q19 What feedback have you received from the school community (principals, teaching colleagues, parents, school librarians, students) about the use of graphic novels as a learning resource?

Q20 How do you envisage graphic novels being used in schools in the future?

Q21 Overall, would you recommend graphic novels be used in New Zealand classrooms as a learning tool? Why or why not? 


\section{Bibliography}

Albright, J. \& Walsh, C. (2003). Jamming visual culture [Electronic version]. Literacy Learning: The Middle Years, 11 (2), 15-21. Retrieved August 9, 2008 from A+Education database.

Andera, S. (2007). Graphic novels in the school library to help promote literacy for boys [Electronic resource]. PNLA Quarterly, 71 (4), 5-8. Retrieved August 7, 2008 from Library Literature and Information Science Full Text database.

Avgerinou, M. \& Ericson, J. (1997). A review of the concept of visual literacy [Electronic version]. British Journal of Education Technology, 28 (4), 280-291. Retrieved January 10, 2009 from Wiley InterScience database.

Babbie, E. (2008). The basics of social research ( $4^{\text {th }}$ ed.). Belmont, CA: Thomson/Wadsworth.

Bergin, M. (2005). Who is reading manga? One high school's story [Electronic version]. Young Adult Library Service, 3 (4), 25-26. Retrieved August 8, 2008 from Library Literature and Information Science Full Text database.

Boyd, J. R. W. (2000). Graphic novels in New Zealand public libraries: a case study of the Palmerston North City Library: submitted to the School of Communications and Information Management Victoria University of Wellington in partial fulfilment of the requirements for the degree of Master of Library and Information Studies. Wellington, NZ: Victoria University of Wellington.

Brenner, R. (2006). Graphic novels 101: FAQ [Electronic version]. Horn Book, 82 (2), 123-125. Retrieved August 7, 2008 from Library Literature and Information Science Full Text database. 
British schools 'dumbing down', says comic critic; [Final edition]. (1998, November 30). Calgary Herald, pp.A4. Retrieved January 3, 2009 from Canadian Newsstand Complete database

Brooks, K. (2008). An impossible passion: young people, contemporary popular culture and reading [Electronic version]. Access, 22 (3), 19-28. Retrieved December 27, 2008 from Informit database.

Carlson, I. (2008). Graphic novels in the classroom [Electronic version]. School Librarian's Workshop, 29 (1), 22-23. Retrieved December 26, 2008 from Library Literature and Information Science Full Text database.

Cazden, C., Cope, B., Fairclough, N., Gee, J., Klantzis, M., Kress, G., Luke, A., Luke, C., Michaels, S., \& Nakata, M. (1996). A pedagogy of multiliteracies: designing social futures [Electronic version]. Harvard Educational Review, 66 (1), 60-92. Retrieved August 19, 2008 from ProQuest 5000 database.

Censorship dateline: schools. (2007). Newsletter on Intellectual Freedom, 56 (6), 241242. Retrieved December 26, 2008 from ProQuest database.

Cho, G., Choi, H., \& Krashen, S. (2005). Hooked on comic book reading: how comic books made an impossible situation less difficult [Electronic version]. Knowledge Quest, 33 (4), 32-34. Retrieved December 26, 2008 from Library Literature and Information Science Full Text database.

Crawford, P. (2004). A novel approach: using graphic novels to attract reluctant readers and promote literacy [Electronic version]. Library Media Connection, 22 (5), 26-28. Retrieved December 28, 2008 from Library Literature and Information Science Full Text database.

Crawford, S. (2002). Graphic novels: An exploration of sequential art. Talespinner, 14, 4-13. 
Creswell, J. W. (2009). Research design: qualitative, quantitative, and mixed methods approaches $\left(3^{r d}\right.$ ed.). Thousand Oaks, CA: Sage Publications.

Creswell, J. W. \& Plano Clark, V. L. (2007) Designing and conducting mixed method research. Thousand Oaks, CA: Sage Publications.

Eisner, W. (2003). Comics and sequential art. Tamarac, FL: Poorhouse Press.

Fitzsimmons, P. (2007). What adolescents are reading and what their teachers are not: between the deformed discourse and disdain of the graphic novel [Electronic version]. Literacy Learning: The Middle Years, 15 (2), 18-22. Retrieved August 5, 2008 from A+Education database.

Foster, K. (2004). Graphic novels in libraries: an expert's opinion [Electronic version]. Library Media Connection, 22 (5), 30-32. Retrieved August 16, 2008 from Library Literature and Information Science Full Text database.

Fraenkel, J. R. \& Wallen, N. E. (2006). How to design and evaluate research in education ( $6^{\text {th }}$ ed.). New York: McGraw-Hill.

Frey, N. \& Fisher, D. (2004). Using graphic novels, anime, and the internet in an urban high school [Electronic version]. English Journal, 93 (3), 19-25. Retrieved July 27, 2008 from Academic Research Library database.

Gardner, H. (1999). Intelligence reframed: multiple intelligences for the $21^{\text {st }}$ century. New York: Basic Books.

Gorman, G. E. \& Clayton, P. R. (1997). Qualitative research for the information professional: a practical handbook. London: Library Association Publishing.

Gorman, M. (2008). Educational manga? [Electronic version]. Library Media Connection, 26 (4), 49. Retrieved January 18, 2009 from Library Literature and Information Science Full Text database. 
Gorman, M. (2003). Getting graphic!: using graphic novels to promote literacy with preteens and teens. Worthington, Ohio: Linworth Publishing.

Gowing, A. (2006). Let them read comics [Electronic version]. Teacher: The National Education magazine, October, 34-37. Retrieved December 27, 2008 from Informit database.

Grbich, C. (2007). Qualitative data analysis: an introduction. London: SAGE.

Heaney, M. J. (2007). Graphic novels: A sure bet for your library [Electronic version]. Collection building, 26 (3), 72-76. Retrieved August 16, 2008 from Emerald database.

Hughes-Hassell, S. \& Rodge, P. (2007). The leisure reading habits of urban adolescents [Electronic version]. The Journal of Adolescent and Adult Literacy, 51 (1), 22-33. Retrieved July 28, 2008 from Academic OneFile.

Jacobs, D. (2007). More than words: comics as a means of teaching multiple literacies [electronic version]. English Journal, 96 (3), 19-25. Retrieved December 26, 2008 from ProQuest database.

Jaeger, R. M. (1984) Sampling in education and the social sciences. New York: Longman

Kan, K. (2003). Getting graphic at the school library [Electronic version]. Library Media Connection, 21 (7), 14-19. Retrieved August 17, 2008 from Business Source Premier database.

Kemper, E. A., Stringfield, S., \& Teddlie, C. (2003). Mixed methods sampling strategy in social science research. In A. Tashakkori \& C. Teddie (Eds.), Handbook of mixed methods in social and behavioural research (pp.273-296). Thousand Oaks, CA: SAGE.

Lamanno, A. A. (2007). Exploring the use of graphic novels in the classroom: does the exposure to non-traditional texts increase the reading comprehension skills and 
motivation of low-functioning adolescent readers?; a thesis in school psychology: submitted in partial fulfilment of the requirements for the degree of doctor of philosophy [Electronic version]. Pennsylvania: Pennsylvania State University The Graduate School College of Education.

Lancy, D \& Hayes, B. (1988). Interactive fiction and the reluctant reader [Electronic version]. The English Journal, 77 (7), 42-46. Retrieved August 8, 2008 from JSTOR database.

Laycock, D. (2007). Going graphic: using graphic novels to engage boys in school reading [Electronic version]. Access, 21 (1), 13-17. Retrieved August 8, 2008 from A+Education database.

Lee-Smith, D. (1994). Comics in New Zealand libraries. New Zealand libraries, 47 (11), 213-214.

Lyga, A. W. \& Lyga, B. (2004). Graphic novels in your media center: a definitive guide. Westport, Conn.: Libraries Unlimited.

McDowall, S. (2004). Opening up a new world: reluctant readers' use of The Game and other stories. Set: Research information for teachers, set 1, 12-14.

McDowall, S. \& Boyd, S. (2003). Playing the game: the impact of classroom use of the CD-ROM The Game and Other Stories on eleven reluctant readers. Wellington: New Zealand Council for Educational Research.

McElmeel, D. L. (2008). The chemistry of graphic novels [Electronic version]. Library Media Connection, 27 (3), 38. Retrieved December 24, 2008 from Academic Search Premier database.

McNicol, S. (2005). Censorship practices and access to information: interviews with school and children's librarians [Electronic resource]. Retrieved June 4, 2009 from http://www.ebase.bcu.ac.uk/docs/Censorship_Practices_Report.doc 
McPherson, K. (2006). Graphic literacy [Electronic version]. Teacher Librarian, 33

(4), 67-69. Retrieved January 4, 2009 from Library Literature and Information Science Full Text database.

Mori, M. (2007). Graphic novels: leading the way to teen literacy and Leadership [Electronic version]. Indiana Libraries, 26 (3), 28-32. Retrieved August 17, 2008 from Library Literature and Information Science Full Text database.

Murray, M. (2007). Exploring the potential of graphic novels [Electronic version]. Scan, 26 (1), 19-21. Retrieved January 17, 2009 from A+Education database.

Norton, B. (2003). The motivating power of comic books: Insights from Archie comic readers[Electronic version]. The Reading Teacher, 57 (2), 141-147. Retrieved August 9, 2008 from ProQuest 5000 database.

Oxford English Dictionary ( $2^{\text {nd }} e d$.) [Electronic version]. (1989). Oxford: Oxford University Press. Retrieved January 11, 2009 from Oxford English Dictionary Online database.

Pickard, A. (2007). Research methods in information. London: Facet Publishing.

Ranker, J. (2007). Using comic books as read-alouds: insights on reading instruction from an English as a second language classroom [Electronic version]. The Reading Teacher, 61 (4), 296-305. Retrieved December 27, 2008 from Academic OneFile database.

Reid, C. (2009). 2008 graphic novel sales up 5\%: Manga off 17\%. Publishers Weekly, Article CA6635333. Retrieved April 25, 2009 from http://www.publishersweekly.com/article/CA6635333.html?rssid=192

Richards, L. (2005). Handling qualitative data: a practical guide. London: Sage Publications. 
Schneider, N. (2007). Holy reading Batman! [Electronic version]. Teaching Pre K-8, 37 (4), 56-57. Retrieved August 7, 2008 from ProQuest 5000 database.

Schwarz, G. E. (2002). Graphic novels for multiple literacies [Electronic version]. Journal of Adolescent \& Adult Literacy, 46 (3), 262-265. Retrieved January 4, 2009 from Academic Search Premier database.

Serchay, D. S. (2004). But those aren't really books! Graphic novels and comic books. In C. A. Nichols (ed.), Thinking outside the book: alternatives for today's teen library collections (21-53). Westport, CT: Libraries Unlimited.

Snowball, C. (2007). Researching graphic novels and their teenage readers [Electronic version]. LIBRES, 17 (1), 1-20. Retrieved July 21, 2008 from Directory of Open Access Journals database.

Snowball, C. (2005). Teenage reluctant readers and graphic novels [Electronic version]. Young Adult Library Services, 3 (4), 43-45. Retrieved January 18, 2009 from Library Literature and Information Science Full Text database.

Teale, W. H., Kim, J., \& Boerman-Cornell, W. (2008). It's elementary! Graphic novels for the K-6 classroom [Electronic version]. Book links, 17 (5), 6-7. Retrieved December 24, 2008 from Academic Search Premier database.

Walton, R. (2007). Creating personal meaning: The graphic novel reading strategies of adolescent males [Electronic version]. Synergy, 5 (1), 41-49. Retrieved August 5, 2008 from A+Education database.

Watts, R. (2003). It's a bird! It's a plane! It's a graphic novel! [Electronic version]. Idiom, 39 (1), 53-58. Retrieved August 5, 2008 from A+Education database.

Weiner, R. (2001). Graphic novels in libraries [Electronic version]. Texas Library Journal, 77 (4), 130-135. Retrieved August 8, 2008 from Library Literature and Information Science Full Text database. 
Weiner, S. (2003). Faster than a speeding bullet: The rise of the graphic novel. New York: NBM.

Welldon, C. (2005). Addressing the gender gap in boys' reading. [Electronic version] Teacher Librarian, 32 (4), 44-45. Retrieved August 8, 2008 from ProQuest 5000 database.

Williams, R. M. (2008). Image, text and story: comics and graphic novels in the classroom [Electronic version]. Art Education, 61 (6), 13-19. Retrieved December 27, 2008 from ProQuest database.

Young, R. (2007). Graphically speaking: the importance of graphic books in a school library collection [Electronic version]. Library Media Connection, 25 (4), 26-28. Retrieved January 11, 2009 from Library Literature and Information Science Full Text database. 
Bryony Walker

INFO 580 research project

Word count: 16,915 